\title{
Veranderingen in werk en vaardigheden
}

Citation for published version (APA):

Fouarge, D. J. A. G. (2017). Veranderingen in werk en vaardigheden. Maastricht University. https://doi.org/10.26481/spe.20170629df

Document status and date:

Published: 29/06/2017

DOI:

$10.26481 /$ spe.20170629df

Document Version:

Publisher's PDF, also known as Version of record

\section{Please check the document version of this publication:}

- A submitted manuscript is the version of the article upon submission and before peer-review. There can be important differences between the submitted version and the official published version of record.

People interested in the research are advised to contact the author for the final version of the publication, or visit the DOI to the publisher's website.

- The final author version and the galley proof are versions of the publication after peer review.

- The final published version features the final layout of the paper including the volume, issue and page numbers.

Link to publication

\footnotetext{
General rights rights.

- You may freely distribute the URL identifying the publication in the public portal. please follow below link for the End User Agreement:

www.umlib.nl/taverne-license

Take down policy

If you believe that this document breaches copyright please contact us at:

repository@maastrichtuniversity.nl

providing details and we will investigate your claim.
}

Copyright and moral rights for the publications made accessible in the public portal are retained by the authors and/or other copyright owners and it is a condition of accessing publications that users recognise and abide by the legal requirements associated with these

- Users may download and print one copy of any publication from the public portal for the purpose of private study or research.

- You may not further distribute the material or use it for any profit-making activity or commercial gain

If the publication is distributed under the terms of Article $25 \mathrm{fa}$ of the Dutch Copyright Act, indicated by the "Taverne" license above, 
Veranderingen in werk en vaardigheden

D I D I E R F O U A R G

O R A T I E 29.06 .2017

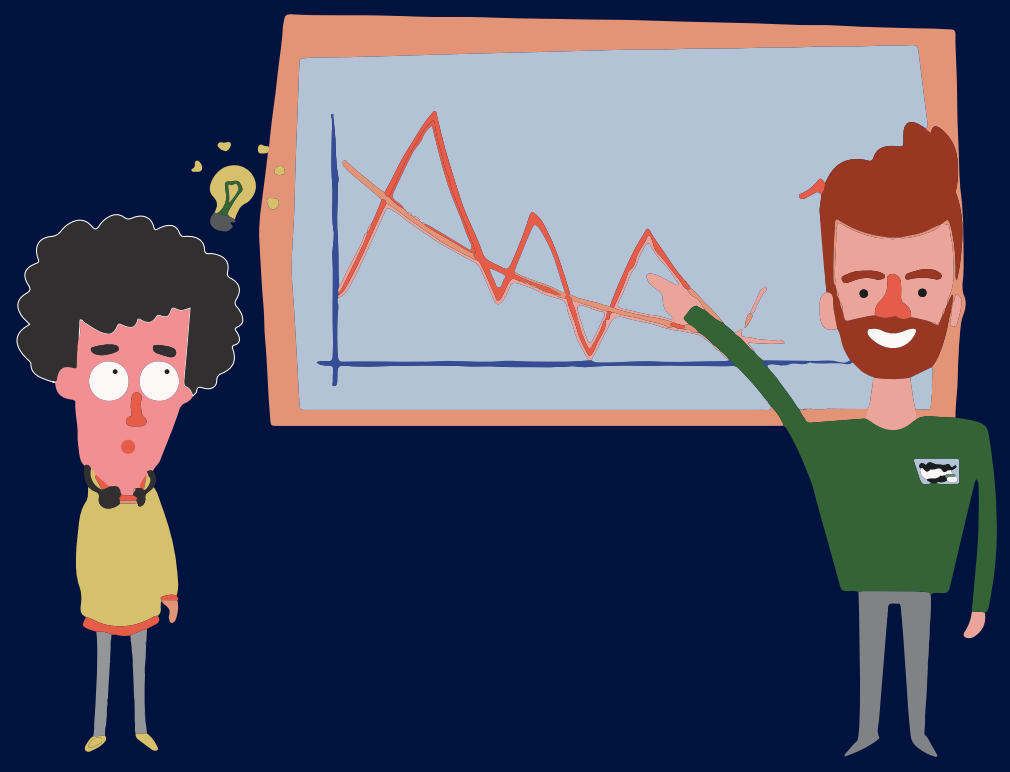


Veranderingen in werk en vaardigheden 
ISBN: 978-90-5321-558-6

De illustratie op het kaft is afkomstig van een animatiefilm die Aggie van Berkum, Sammy Eschweiler, Danique Jaspers, Nandisa Ludidi en Daphne Szlosarczyk (toen studenten aan de Zuyd Hogeschool) hebben ontworpen voor het Project Onderwijs-Arbeidsmarkt van het Researchcentrum voor Onderwijs en Arbeidsmarkt. De volledige animatie is te vinden op: https://www.youtube.com/watch?v=XpEaElUCnmg 


\section{Veranderingen in werk en vaardigheden}

Rede uitgesproken bij de aanvaarding van het ambt van hoogleraar Dynamics of Skills Allocation aan de School of Business and Economics, Maastricht University.

Maastricht, 29 juni 2017

Door Dr. Didier Fouarge 

Mevrouw de Rector Magnificus,

Waarde collega's, beste vrienden, ma chère famille,

In de meeste geïndustrialiseerde landen is de dynamiek in vraag en aanbod van vaardigheden in de afgelopen decennia aanzienlijk toegenomen. De arbeidsmarkt is flexibeler geworden waardoor de arbeidsmobiliteit toeneemt. Door de upgrading van de opleidingseisen neemt het belang van een goede opleiding toe en stijgt de noodzaak om zich bij te scholen. In deze veranderende arbeidsmarkt is het van groot belang dat wij beter begrijpen hoe het aanbod van vaardigheden in de potentiële beroepsbevolking beter kan aansluiten op de door werkgevers gevraagde competenties. Hierop zal mijn leerstoel zich richten, met bijzondere aandacht voor sorteringsprocessen in opleiding en beroep over de individuele levensloop en de betekenis daarvan voor bedrijven. Onder jongeren gaat het hierbij om het sorteren in het onderwijs en de beroepskeuze. Later in de loopbaan, gaat het om de keuze om opnieuw te investeren in menselijk kapitaal (bijvoorbeeld door middel van scholing), om aanpassingen in het arbeidsaanbod (wel of niet werken en aantal gewerkt uren) en beroepenmobiliteit. Op bedrijfsniveau, gaat het om het wervings- en scholingsbeleid van werkgevers bij veranderingen in de organisatie en/of in het productieproces. Deze dynamische individuele beslissingen van de werknemers en werkgevers kan worden gedreven door zowel voorkeuren als veranderende omstandigheden op de arbeidsmarkt.

De relevantie van de gekozen focus kan bezien worden vanuit individueel, werkgever en macro-economisch perspectief. Vanuit een individueel perspectief, zal het optimaliseren van de allocatie tussen de vaardigheden verkregen in de kinderjaren, in het onderwijs, en door ervaring en cursussen op de vraag van werkgevers, naar verwachting resulteren in een hoger loon, lager risico op werkloosheid, betere carrièreperspectieven, hogere werktevredenheid, en minder spijt van studie- en beroepskeuze. Vanuit een werkgeversperspectief zorgt een optimale allocatie tussen de aangeboden vaardigheden en de vraag vanuit arbeidsorganisaties er voor dat werkgevers hun vacatures kunnen vervullen en dat ze op een bevredigende manier kunnen voldoen aan hun gewenste niveau van productie en innovatie. Vanuit een macro-economisch perspectief, resulteert het optimaliseren van de allocatie tussen vraag en aanbod in meer economische groei en grotere maatschappelijk opbrengsten van investeringen in vaardigheden. 
In deze oratie wil ik mij richten op twee onderwerpen van mijn leerstoel: 1) de veranderingen in de vraag naar vaardigheden op de arbeidsmarkt, en 2) de invloed van transparante informatie over vraag en aanbod op de arbeidsmarkt op de studiekeuze van jongeren. Ik sluit af met enkele implicaties voor beleid.

\section{Veranderingen in vraag naar vaardigheden}

In het onderzoek naar de dynamiek in vraag naar en aanbod van vaardigheden onderscheid ik twee belangrijke dimensies. De eerste betreft onderzoek op micro niveau naar de dynamiek in arbeidsaanbodbeslissingen. Het gaat hierbij om de opleidingskeuze van jongeren, de beroepskeuze van jongeren en volwassenen, beroepenmobiliteit, migratie en veranderingen in het arbeidsaanbod in de extensieve en intensieve marge alsook de pensioneringsbeslissing. Deze arbeidsmarktuitkomsten zijn enerzijds gedreven door instituties (Jung en Kuhn, 2014) en veranderingen in beleidscontext (Montizaan et al., 2010) en de macroeconomische situatie (Mortensen, 1994). Arbeidsmarktuitkomsten en veranderingen die mensen meemaken op de arbeidsmarkt zijn anderzijds ook gedreven door hun eigen cognitieve en niet-cognitieve vaardigheden en economische voorkeuren (bijvoorbeeld voor tijd en risico) (Almlund et al., 2011; Borghans et al., 2008a). Met verschillende collega's heb ik de afgelopen jaren gewerkt aan onderzoek op die terreinen, en deze lijn wil ik voortzetten in mijn nieuwe rol. Ik kom later in deze oratie terug op vaardigheden en voorkeuren in het kader van de opleidingskeuze. De tweede dimensie van mijn onderzoek naar dynamiek in vraag en aanbod van vaardigheden betreft de veranderingen, op macro niveau, en de te verwachten veranderingen door de tijd in de opleidingenen beroepenstructuur. Hier ga ik nu dieper op in en bespreek achtereenvolgend veranderingen in opleidingsniveau en vaardigheden, polarisatie op de arbeidsmarkt en de relatie tussen loon en vaardigheden. 


\subsection{Opleidingsniveau ${ }^{1}$}

De samenstelling van de werkzame beroepsbevolking verandert continu als gevolg van veranderingen aan de aanbod- en vraagkant van de arbeidsmarkt. In landen van de OESO (Organisatie voor Economische Samenwerking en Ontwikkeling) is het percentage hoogopgeleiden in de bevolking gegroeid van $22 \%$ in 2000 naar 35\% in 2015 (OECD, 2016). Onder 25-34 jarigen is in $201542 \%$ hoogopgeleid. De stijging van het opleidingsniveau van de werkzame beroepsbevolking in Nederland is duidelijk te zien in figuur 1 . Het aandeel hboen wo-gediplomeerden is in de afgelopen twintig jaar continu gestegen, terwijl het aandeel werkenden met een diploma op hoogstens vmbo-niveau continu is afgenomen. Het aandeel mbo'ers blijft plus minus constant.

Figuur 1: Aandeel werkenden naar opleidingsniveau, 1996-2016

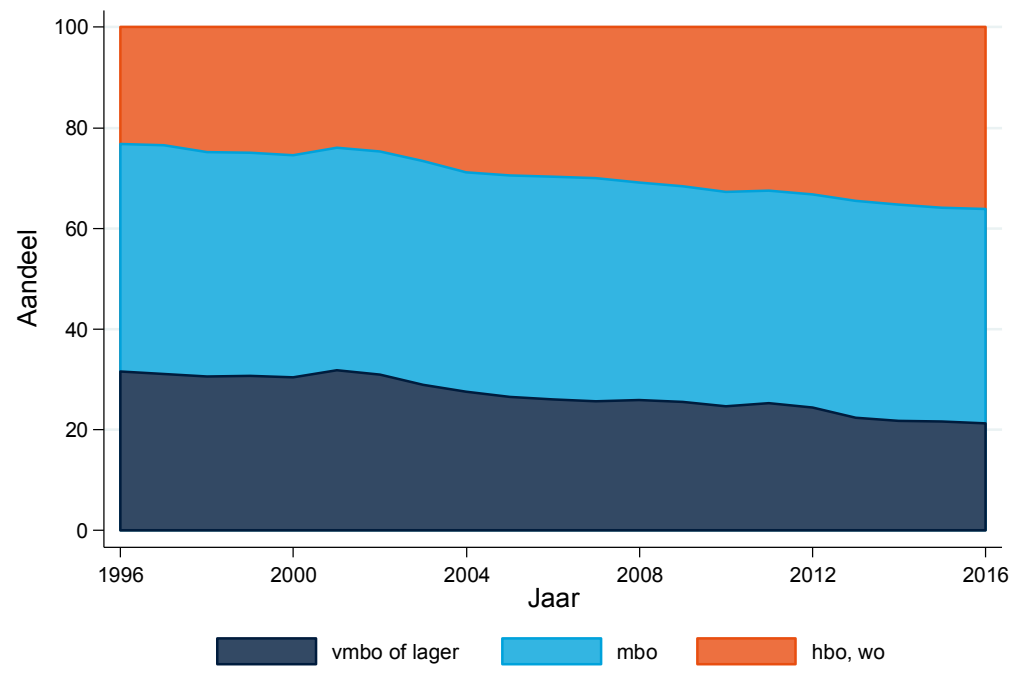

Bron: EBB

\footnotetext{
${ }^{1}$ Wanneer ik hier over beroepen spreek dan gaat het doorgaans om beroepsgroepen zoals wij deze hebben gedefinieerd in een gezamenlijk project met CBS (Centraal Bureau voor de Statistiek) (ROA/CBS, 2015). De gebruikte data voor de ontwikkeling van beroepen zijn afkomstig van de Enquête Beroepsbevolking (EBB) van CBS.
} 
Een vergelijkbaar plaatje komt naar voren als we kijken naar de verdeling van de werkenden over beroepen, uitgesplitst naar het modaal opleidingsniveau van de werkenden in die beroepen (figuur 2). ${ }^{2}$ Het aandeel werkenden in hoogopgeleide beroepen is gestegen, dat in laagopgeleide beroepen gedaald. Het aandeel werkenden in mbo-beroepen is nauwelijks veranderd. In de afgelopen twintig jaar is de beroepenstructuur dus verschoven naar een gemiddelde hoger opleidingsniveau.

Figuur 2: Aandeel werkenden naar modaal opleidingsniveau van beroepen waarin zij werkzaam zijn, 1996-2016

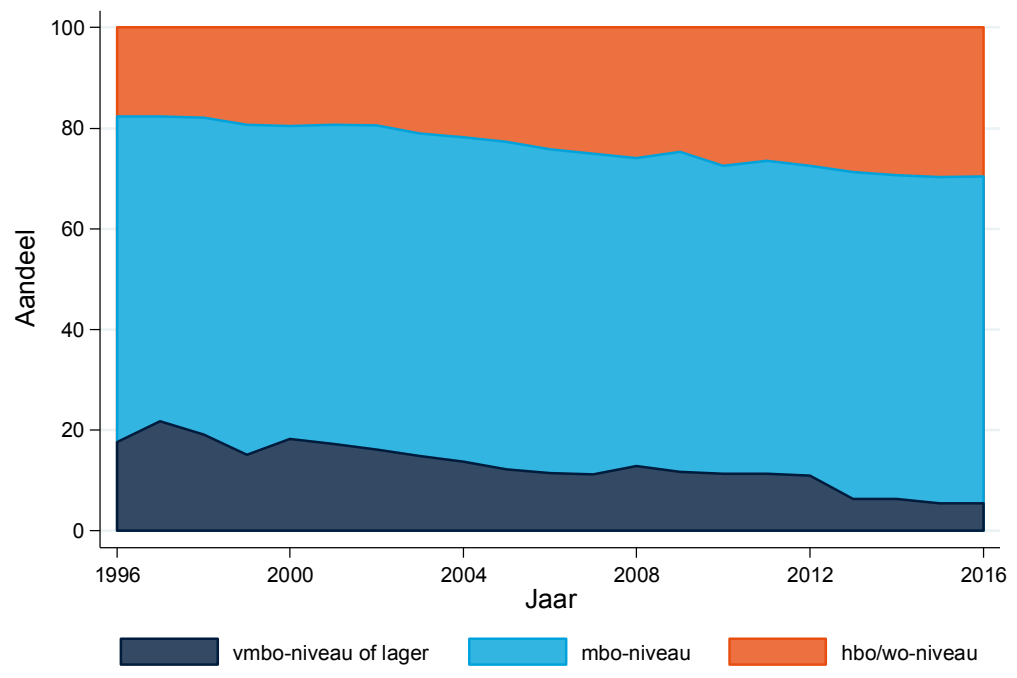

Bron: EBB

In onderzoek met mijn ROA collega's hebben wij becijferd dat de stijging in opleidingsniveau in Nederland tussen de jaren tachtig en nu ongeveer 2 opleidingsjaren bedraagt (Bijlsma et al., 2015; ROA, 2015). Overigens lijkt het

2 Figuur 2 verschilt van figuur 1 omdat hier gekeken wordt naar het modaal opleidingsniveau van de werkenden in beroepen. In sommige beroepen werken hoofzakelijk hoogopgeleiden (bijvoorbeeld in beroep 'artsen'), in andere beroepen vooral middelbaar opgeleiden (bijvoorbeeld het beroep 'secretaresses'), terwijl in andere beroepen de mix aan opleidingsachtergronden groter is (bijvoorbeeld in beroep 'bedieners mobiele machines' werken bijna evenveel mbo'ers als vmbo'ers). 
tempo van deze skills upgrading te vertragen. In de jaren 1981-1985 steeg het opleidingsniveau met 0,47 opleidingsjaren. De stijging tussen 2005-2010 bedroeg 0,19 opleidingsjaren. Wij hebben onderzocht aan de hand van een shift-share analyse in welke mate de stijging van het gemiddelde opleidingsniveau van werkenden het gevolg is van verschuivingen in de beroepenstructuur dan wel van hogere aanstellingseisen binnen beroepen. De gevolgen van de verschuivingen in de beroepenstructuur voor het gemiddelde opleidingsniveau kan worden gezien als het structuureffect (shift). De verschuivingen van het gemiddelde opleidingsniveau binnen een beroep kan worden gezien als een verdringings- of substitutie-effect (share). Wij kwamen tot de conclusie dat ongeveer $40 \%$ van de stijging in het gemiddelde opleidingsniveau verklaard kan worden uit veranderingen in de beroepenstructuur (beroepen waar veel hoogopgeleiden werken zijn sneller gegroeid). Dit wil zeggen dat de toename in het gemiddeld opleidingsniveau meer het gevolg is van stijgende opleidingsniveaus binnen beroepen dan van verschuivingen in de beroepenstructuur. Dit zou er op duiden dat deze skills upgrading de steeds hogere kwalificatie-eisen reflecteert die werkgevers stellen aan werknemers die werkzaam zijn in hun organisaties. Onze analyse is dus dat de hogere kwalificatieeisen vooral arbeidsvraag-gestuurd zijn bijvoorbeeld door technologische vernieuwingen (Katz en Autor, 1999) of meer complexe organisatiestructuren (Caroli en Van Reenen, 2001).

\subsection{Vaardigheden}

In een productiemodel bepalen de vaardigheden van mensen de taken die zij uitvoeren. Hoogwaardige vaardigheden zijn nodig voor het uitvoeren van hoogwaardige taken en, naar verwachting, resulteren hoogwaardige vaardigheden in hogere productiviteit en lonen. Maar sommige taken kunnen ook door machines worden uitgevoerd. Mens-taken en machine-taken, die gebundeld zijn in beroepen, kunnen complementair aan elkaar zijn, maar ook substitueerbaar zijn. David Autor en coauteurs (Autor et al., 2003) wijzen naar technologische ontwikkelingen als verklaring voor veranderingen in de beroepenstructuur. Technologische ontwikkelingen leiden tot een toegenomen complexiteit van het werk en het groeiend belang van specifieke vaardigheden zoals ict-vaardigheden, probleemoplossend vermogen, en communicatieve en sociale vaardigheden (Borghans et al., 2014; Green, 2012). Met het beschikbaar komen van data als PIAAC (Programme for the International Assessment of Adult 
Competencies), en de NSS (de Nederlandse Skills Survey), kunnen wij analyses uitvoeren van de relatie tussen vaardigheden en veranderingen in het beroepenlandschap. PIAAC is een internationaal onderzoek van de OESO naar het niveau en het gebruik van vaardigheden onder mensen tussen 16 en 65 jaar. De vaardigheden zijn gemeten door middel van uitvoerige, objectieve testen (OECD, 2013). Het betreft functionele vaardigheden die nodig zijn om informatie uit het dagelijks leven te begrijpen en te gebruiken (Buisman et al., 2013). Het probleemoplossend vermogen in digitale omgevingen (kortweg: probleemoplossend vermogen) wordt daarin gemeten en verwijst naar het vermogen om digitale technologie te gebruiken om problemen uit het dagelijks leven op te lossen. ${ }^{3}$ PIAAC bevat daarnaast een aantal vragen over ict-gebruik op het werk. Op basis van deze vragen kan een index worden gemaakt van het niveau van computergebruik op het werk: $0=$ geen gebruik, $1=$ eenvoudig gebruik, 2 = matig gebruik, 3 = complex gebruik. Beroepen kunnen vervolgens worden ingedeeld naar het niveau van probleemoplossend vermogen van de werkenden in die beroepen (die ik hier indeel in kwintielgroepen) en het percentage werkenden met een matig of complex gebruik van computers (die ik hier indeel in drie gelijke groepen: laag, gemiddeld, hoog).

Figuur 3 en 4 laten zien dat de werkgelegenheid -gemeten in de EBB- het sterkst is gegroeid in beroepen met een hoog niveau van probleemoplossend vermogen en hoog niveau van computer gebruik. ${ }^{4}$ De werkgelegenheid is het minste gegroeid in beroepen met een laag niveau van probleemoplossend vermogen en laag niveau van complexiteit van computergebruik. Ook beroepen waarin taakautonomie belangrijk is, zijn sterk gegroeid (Fouarge, 2017).

\footnotetext{
${ }^{3}$ De testscores voor de verschillende vaardigheden worden weergegeven op een schaal van 0 tot 500 punten. In PIAAC kregen personen zonder computervaardigheden de test voor probleemoplossend vermogen niet voorgelegd (10 procent van de respondenten in Nederland). Voor hen is de score op een lage waarde (90) gezet.

${ }^{4}$ Zie ook Fouarge et al. (2017) waar wij met een shift-share analyse laten zien dat de groei in beroepen vrijwel geheel kan worden toegeschreven aan veranderingen in de beroepen zelf, en nauwelijks aan veranderingen in de werkgelegenheidsstructuur van sectoren.
} 
Figuur 3: Werkgelegenheidsontwikkeling naar niveau van probleemoplossend vermogen

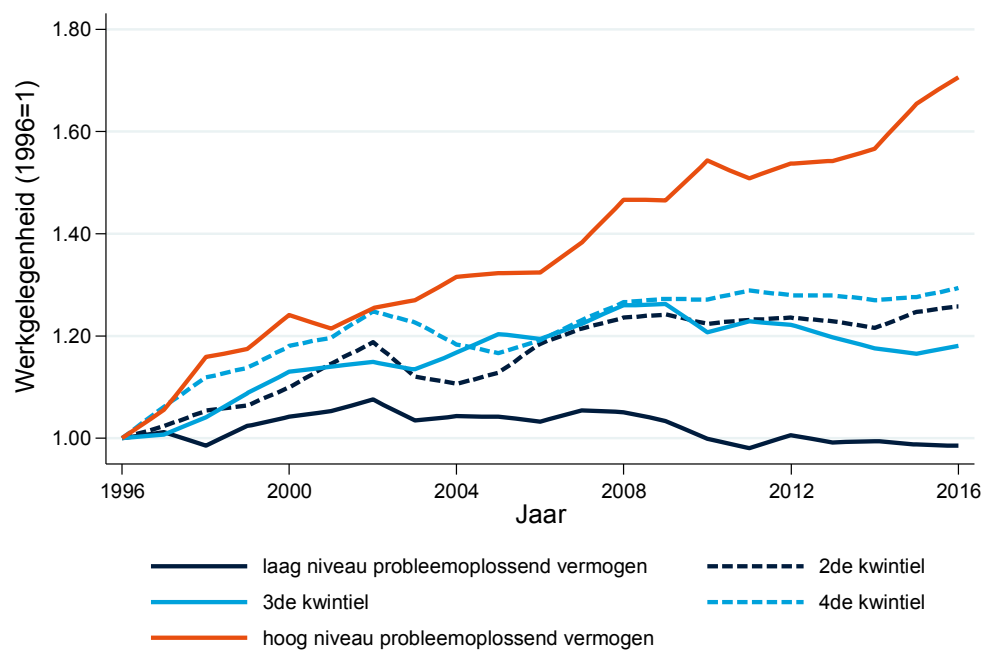

Bron: EBB, PIAAC

Figuur 4: Werkgelegenheidsontwikkeling naar intensiteit van PC gebruik op het werk

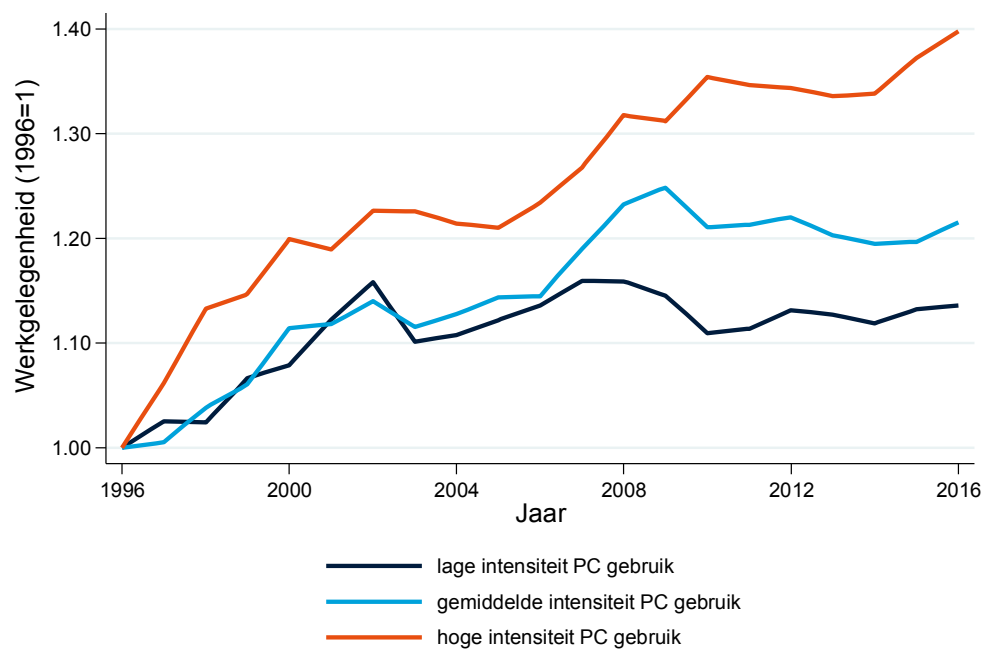

Bron: EBB, PIAAC 
Collega's Lex Borghans en Bas ter Weel hebben eerder laten zien dat interpersoonlijke vaardigheden van belang zijn op de arbeidsmarkt in Duitsland en Engeland: de correlatie tussen interpersoonlijke vaardigheden en het loon is positief (Borghans et al., 2008b). In Duitsland is deze correlatie sterker geworden tussen 1979 en 1998. In een recent gepubliceerd artikel wijst Catherine Weinberger (2014) op de groeiende complementariteit tussen cognitieve vaardigheden en sociale vaardigheden (oftewel soft skills) op de arbeidsmarkt in de Verenigde Staten. Zowel de werkgelegenheid als de lonen zijn sterker gegroeid in beroepen met zowel een hoog niveau van cognitieve vaardigheden als een hoog niveau van sociale vaardigheden dan in beroepen waar slechts een van deze vaardigheden dominant is. Een vergelijkbare ontwikkeling zien wij ook in Nederland.

In figuur 5 relateer ik de werkgelegenheidsontwikkeling in beroepen in de afgelopen 20 jaar in Nederland aan het niveau van probleemoplossend vermogen, en het niveau van interpersoonlijke vaardigheden van werkenden in die beroepen. De werkgelegenheidsontwikkeling is wederom gemeten aan de hand van EBB data. Het probleemoplossend vermogen is gemeten in PIAAC. Interpersoonlijke vaardigheden zijn gemeten in de eerste peiling van de NSS gehouden in 2012 (ter Weel en Kok, 2013). De NSS heeft als doel de taken die mensen op het werk uitvoeren te meten alsook de vaardigheden die voor deze taken nodig zijn. Het is een afspiegeling van de al langer lopende British Skills Survey. Interpersoonlijke vaardigheden zijn gemeten volgens Borghans et al. (2008b) en hebben betrekking op bijvoorbeeld 'samenwerken in een team met anderen'. De figuur laat zien dat de werkgelegenheid nagenoeg onveranderd is gebleven in beroepen met een laag niveau van probleemoplossend vermogen en een laag niveau van interpersoonlijke vaardigheden (bijvoorbeeld 'schoonmakers', 'hulpkrachten bouw en industrie', 'veetelers', en 'lassers en plaatwerkers'). De werkgelegenheid is het sterkst gegroeid in beroepen met zowel een hoog niveau van probleemoplossend vermogen als een hoog niveau van interpersoonlijke vaardigheden (bijvoorbeeld 'elektrotechnisch ingenieurs', 'managers ICT', 'specialisten personeels- en loopbaanontwikkeling' en 'managers zorginstellingen'). Dit suggereert dat deze vaardigheden steeds belangrijker worden voor het uitvoeren van taken op het werk, en in het productieproces van bedrijven. Het suggereert ook dat de complexiteit van het werk toeneemt (Fouarge en de Grip, 2013). 
Figuur 5: Werkgelegenheidsontwikkeling naar niveau van probleemoplossend vermogen en interpersoonlijke vaardigheden

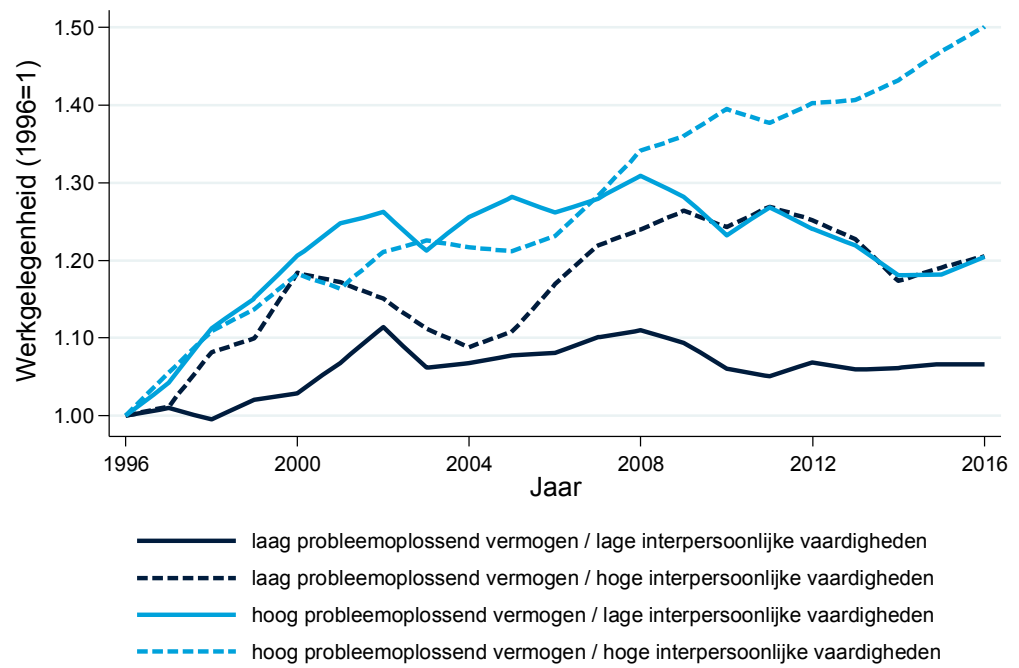

Bron: EBB, PIAAC, NSS

Een probleem bij deze analyses is dat ik, bij gebrek aan data, de ontwikkeling in de tijd van de werkgelegenheid in beroepen relateer aan het niveau van vaardigheden van werkenden in die beroepen op een gegeven moment in de tijd. Hierdoor kan ik de ontwikkeling in de tijd van het niveau van vaardigheden zelf niet inzichtelijk maken. Met andere woorden: ontwikkelingen tussen beroepen zijn zichtbaar, die binnen beroepen niet. Dat ontwikkelingen binnen beroepen relevant zijn, illustreert ons onderzoek met collega's Ahmed Elsayed en Andries de Grip waarin wij laten zien dat de vermindering van de loonkloof tussen deeltijd en voltijd werkende vrouwen in Engeland tussen 1997 en 2012 voor een belangrijk deel verklaard kan worden door de convergentie in computer gebruik en cognitieve taken binnen beroepen, taken die geassocieerd zijn met een hogere beloning (Elsayed et al., 2017).

Dankzij de verwachte nieuwe ronde van PIAAC en NSS data, zullen in de toekomst meer onderzoeksmogelijkheden zijn op dit gebied. Op macroniveau denk ik bijvoorbeeld aan een vertaalslag van de ROA arbeidsmarktprognoses (ROA, 2015) naar prognoses voor de toekomstige vraag naar skills en taken zodat er beter 
zicht ontstaat op uitwijkberoepen voor werkenden in krimpberoepen. Op microniveau denk ik aan onderzoek naar de relatie tussen het uitvoeren van taken en de mate waarin men informeel leert van deze taken (binnen het NRO project Levenslang leren en competentieontwikkeling met o.a. collega's Barbara Belfi, Peter van Eldert, Andries de Grip, Annemarie Künn-Nelen en Davey Poulissen) en naar de relatie tussen taken op het werk, inzetbaarheid op latere leeftijd en de uittredingsbeslissing (binnen het Netspar onderzoek in samenwerking met collega's Andries de Grip en Raymond Montizaan). Wat dat laatste betreft wijst voorlopig onderzoek (zie figuur 6) voor Engeland naar een kleiner wordende kloof in probleemoplossend vermogen en computergebruik tussen jong en oud (Hornstra et al., 2017).

Figuur 6: Leeftijdskloof in probleemoplossend vermogen en computergebruik, Engeland 1997-2012

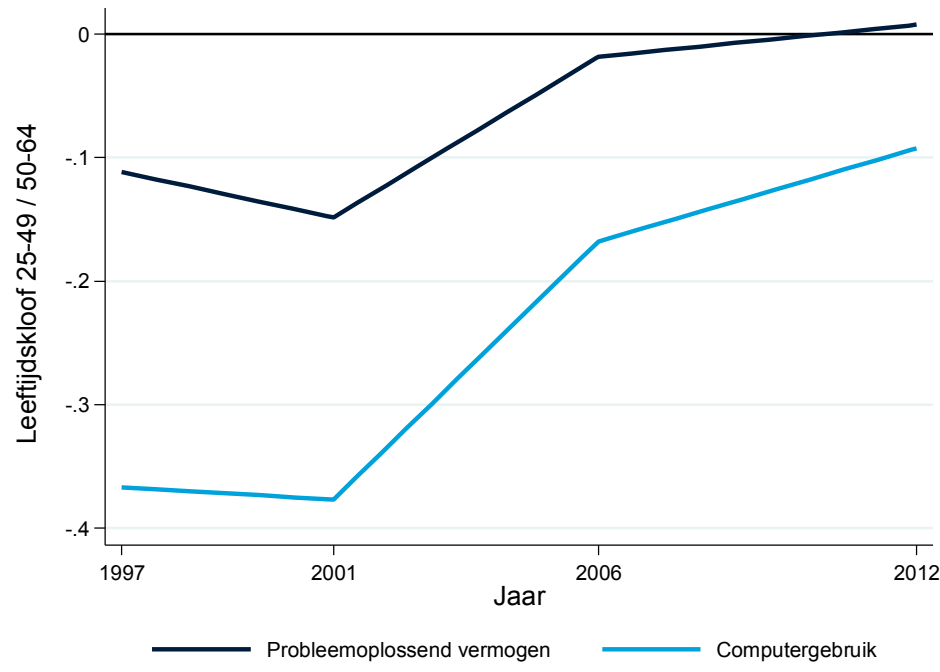

Bron: British Skills Survey

\subsection{Polarisatie}

De veranderende vraag naar vaardigheden op de arbeidsmarkt heeft kwalitatieve gevolgen als het gaat om het soort taken dat aan belang toeneemt, maar ook kwantitatieve gevolgen omdat sommige taken er helemaal niet meer toedoen 
doordat mens-taken door machines of robots kunnen worden uitgevoerd of elders in het buitenland. In de wetenschappelijke literatuur, maar ook in beleid, is afgelopen jaren veel aandacht geweest voor baanpolarisering. Baanpolarisering houdt in dat er sprake is van een verminderde vraag naar banen en beroepen in het middensegment (vaak bestaand uit routinematige cognitieve en handmatige taken) terwijl de vraag in laagbetaalde (vaak bestaand uit niet-routinematige handmatige taken) en hoogbetaalde beroepen (niet-routinematige cognitieve taken) relatief groeit. Wetenschappelijk onderzoek verwijst naar veranderingen in de organisatie van het werk, globalisering, en automatisering als verklaringen voor polarisering op de arbeidsmarkt (Caroli en Van Reenen, 2001; Autor et al., 2003; Autor en Dorn, 2013). De polarisering op de arbeidsmarkt is goed gedocumenteerd voor de Verenigde Staten (Autor et al., 2006, 2008), het Verenigd Koningrijk (Goos en Manning, 2007), Duitsland (Spitz-Oener, 2006) en andere OESO en Europese landen (Goos et al., 2009, 2014; Michaels et al., 2014). Ook voor Nederland is deze polarisatietendens in publicaties van het Centraal Planbureau (Van den Berge en ter Weel, 2015; ter Weel, 2015) en Centraal Bureau voor de Statistiek besproken (Smits en de Vries, 2015).

Polarisatie kan zichtbaar worden gemaakt door de beroepen te sorteren naar de hoogte van het loon om vervolgens te kijken naar de verandering in het werkgelegenheidsaandeel in een bepaalde periode. De donkerblauwe lijn in figuur 7 doet dit, en het laat inderdaad zien dat in de afgelopen twintig jaar het werkgelegenheidsaandeel in het middensegment gedaald is. ${ }^{5}$ Dat van laagbetaalde en hoogbetaalde beroepen is gestegen. In het wetenschappelijke debat (Frey en Osborne, 2017) en in beleidsdiscussies (SER, 2016) is, zoals gezegd, veel nadruk gelegd op de rol van automatisering en robotisering als verklaring voor de relatieve krimp in het middensegment, omdat het banen betreft met overwegend routinematige taken (denk hierbij aan de bankbediende en de secretaresse) die efficiënter uitgevoerd kunnen worden met behulp van nieuwe technologieën. Als automatisering inderdaad de verklaring is voor polarisering, dan zou je verwachten dat de automatiseringskans het hoogst is in het middensegment en het laagst in lage en hoge loonberoepen. Om dit te toetsen heb ik in de figuur de automatiseringskans van beroepen (Deloitte, 2014) afgezet tegen het brutoloon in die beroepen (lichtblauwe lijn in figuur 7). De figuur

\footnotetext{
${ }^{5}$ Het brutoloon, gemeten in het Sociaal Statistisch Bestand (SSB), betreft enkel het loon van werkenden in loondienst. Het bruto uurloon is verkregen door het loon te delen met de gewerkte uren in EBB en is ingedeeld in percentielen.
} 
suggereert dat vooral mensen met een relatief hoog loon een kleine kans hebben hun huidige baan te verliezen als gevolg van automatisering. Dit zou tevens kunnen betekenen dat de waargenomen toename in het arbeidsmarktaandeel van laagbetaalde beroepen niet zal aanhouden, omdat ook deze beroepen voor een belangrijk deel geautomatiseerd zouden kunnen worden (Fouarge en Levels, 2016). Dit lijkt figuur 8 ook te suggereren. In de periode 1996-2006 was polarisering duidelijker zichtbaar dan in de periode 2006-2016: in deze laatste periode is vooral sprake van werkgelegenheidsgroei in de beter betaalde beroepen, terwijl de relatieve groei in de laagbetaalde beroepen nul of negatief was. ${ }^{6}$ De conclusie dat automatisering zowel de lage als de middelbetaalde beroepen treft is in lijn met bevindingen van Graetz en Michaels (2015). ${ }^{7}$

Voorbeelden van beroepen met een laag loon en een hoog automatiseringsrisico zijn kassamedewerkers en keukenhulpen. Aan de andere kant van het spectrum zijn artsen en ict-managers voorbeelden van beroepen met een hoog loon en laag automatiseringsrisico. Typische beroepen in het middensegment zijn secretaresses, elektriciens en elektronicamonteurs, apothekersassistenten, bouwarbeiders afbouw, loodgieters en pijpfitters, sociaal werkers, groeps- en woonbegeleiders, fotografen en interieurontwerpers, en timmerlieden. Veel van deze beroepen hebben een hoog automatiseringsrisico (bijvoorbeeld secretaresses), maar niet allemaal (fotografen en interieurontwerpers). Dit rijtje beroepen brengt mij bij een tweede, vaak genoemde, verklaring voor polarisering: internationalisering. Voor een aantal van die beroepen in het middensegment is offshoring van activiteiten zeker een mogelijkheid, denk hierbij aan secretariële werkzaamheden, of zelfs apothekersassistenten als de wetgever de markt voor medicijnen zou dereguleren. Voor andere beroepen is offshoring niet goed denkbaar (sociaal werkers, groeps- en woonbegeleiders) of niet handig voor de consument (loodgieters en pijpfitters). Vervolgonderzoek zal moeten uitwijzen welke mechanismen in welke mate verantwoordelijk zijn voor polarisering: automatisering, internationalisering, of misschien ook starheid van lonen waar ik zo meteen op in ga.

\footnotetext{
${ }^{6}$ Ik kan niet uitsluiten dat de grote recessie van invloed is geweest op deze verandering. Beaudry et al. (2016) laten zien dat de vraag naar cognitieve taken in de Verenigde Staten na een lange periode van groei vanaf 2000 is gedaald. Dit lijkt in Nederland niet aan de orde.

${ }^{7}$ Het laatste woord hierover is nog lang niet gezegd: Acemoglu et al. (2017) laten zien dat robotisering grote negatieve effecten heeft gehad op de werkgelegenheid in de Verenigde Staten terwijl Arntz et al. (2016) concluderen dat slechts $9 \%$ van de banen in de OESO te automatiseren zijn.
} 
Figuur 7: Verandering in werkgelegenheidsaandeel van beroepen 1996-2016 en automatiseringskans van beroepen, naar loonniveau in 2009

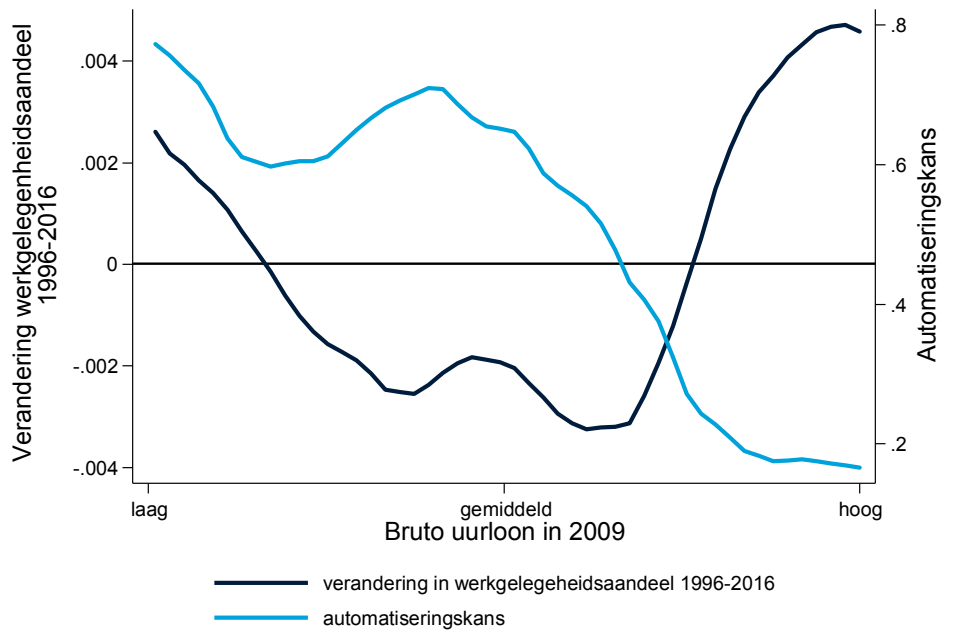

Bron: EBB, SSB, Deloitte (Frey/Osborne)

Figuur 8: Verandering in werkgelegenheidsaandeel van beroepen 1996-2006 en 2006-2016, naar loonniveau in 2009

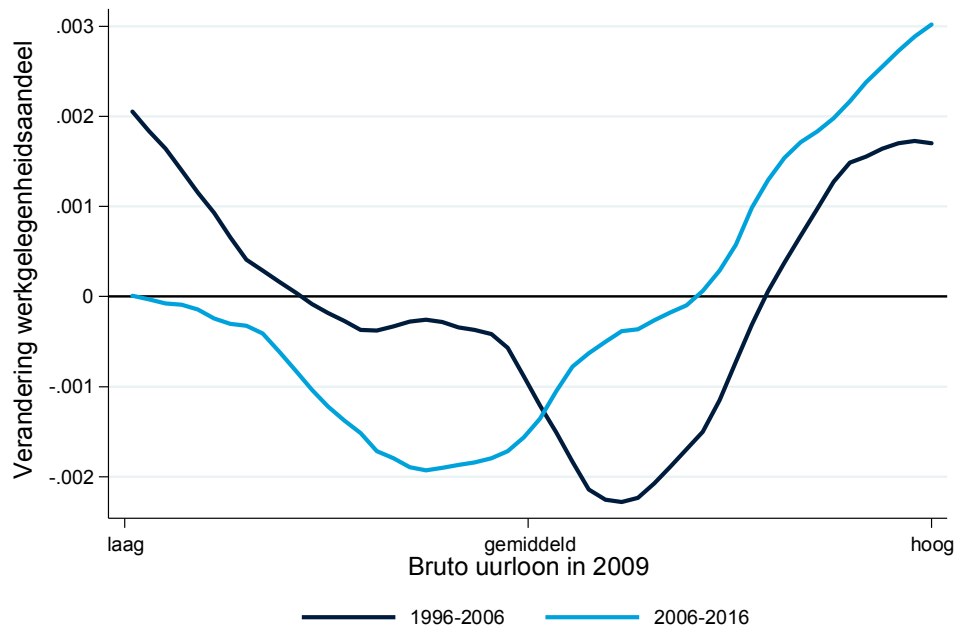

Bron: EBB, SSB 


\subsection{Lonen en vaardigheden}

Op microniveau is het loonrendement van vaardigheden (zoals gemeten in PIAAC) door Eric Hanushek en co-auteurs aangetoond (Hanushek et al., 2015). Het rendement verschilt echter tussen landen en over de levensloop. Als wij voor Nederland het loon in beroepen afzetten tegen het niveau van probleemoplossend vermogen van werkenden in die beroepen, dan blijkt er inderdaad sprake te zijn van een positief verband: in beroepen waar het niveau van probleemoplossend vermogen hoger is, is het uurloon ook hoger (figuur 9).

Figuur 9: Relatie tussen bruto uurloon en probleemoplossend vermogen, naar beroep

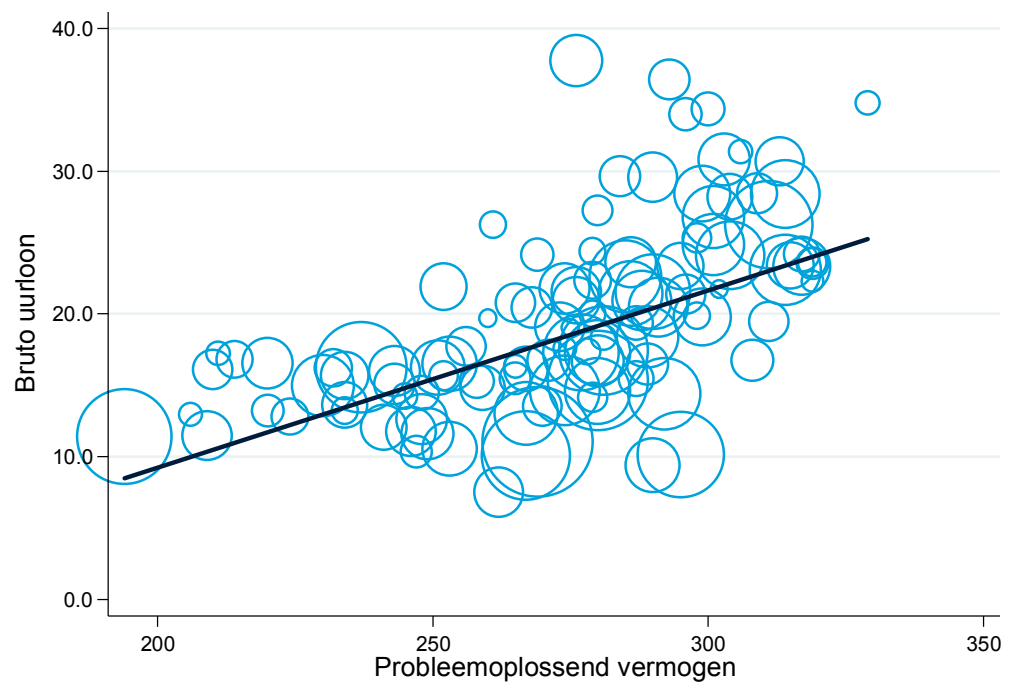

Bron: EBB, PIAAC, SSB

Gelet hierop, zou je verwachten dat grote verschillen in het niveau van vaardigheden tussen mensen in beroepen zich zou vertalen in grote verschillen in beloning binnen die beroepen. Figuur 10 laat echter zien dat hier geen sprake van is, en dit is een eerste puzzel m.b.t. Ionen en vaardigheden. ${ }^{8}$ Dit is merkwaardig en verdient nader onderzoek. Hierbij kan worden gedacht aan de

\footnotetext{
${ }^{8}$ De figuur relateert de standaard deviatie van het probleemoplossend vermogen en het bruto uurloon van werkenden binnen beroepen aan elkaar.
} 
rol die functionele vaardigheden spelen bij het toegang verschaffen tot bepaalde beroepen, waarbij nadien andere vaardigheden een belangrijkere rol gaan spelen (bijvoorbeeld vakvaardigheden, leervermogen, maar ook soft skills). Het kan echter ook zijn dat institutionele arrangementen er voor zorgen dat verschillen in functionele vaardigheden niet weerspiegeld worden in verschillen in beloningen binnen een beroep.

Figuur 10: Relatie tussen standaard deviatie van bruto uurloon en standaard deviatie van probleemoplossend vermogen, naar beroep

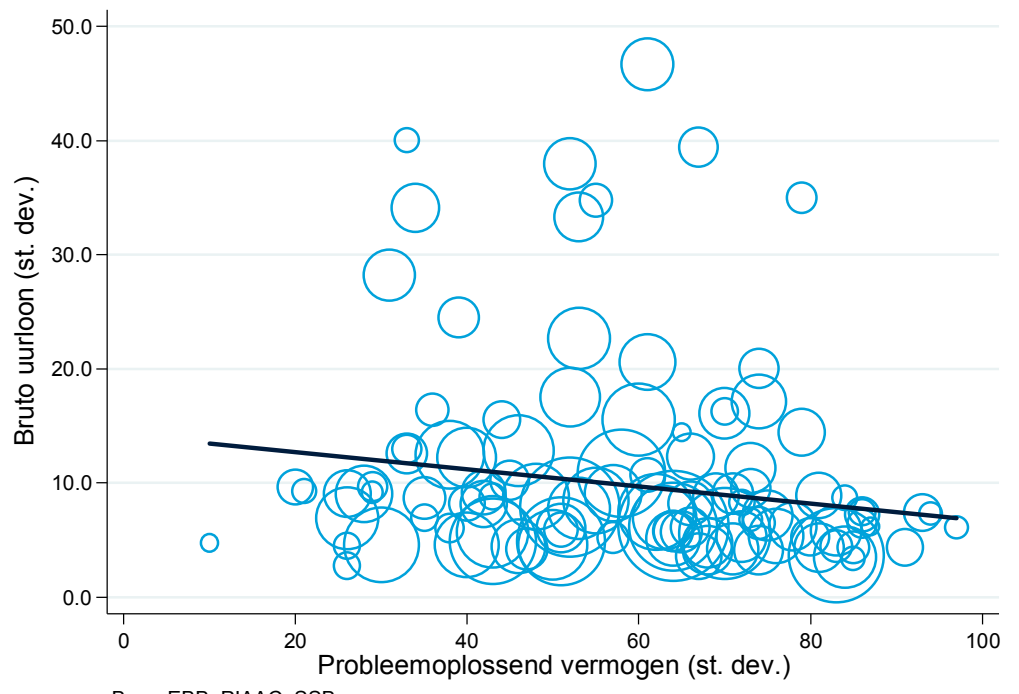

Bron: EBB, PIAAC, SSB

Een tweede puzzel met betrekking tot lonen en vaardigheden betreft de loonontwikkeling zelf in de afgelopen 20 jaar. Figuur 7 liet zien dat de werkgelegenheidsontwikkeling in het middensegment in relatieve termen achter is gebleven bij de ontwikkeling in lage en hoge loonberoepen. Als vraag en aanbod optimaal op elkaar reageren, dan zou je verwachten dat de loonontwikkeling in het middensegment ook achter zou blijven in relatieve termen. Dit is echter niet wat figuur 11 laat zien. De figuur is afgeleid van gezamenlijk onderzoek met Wendy Smits en andere CBS collega's (Fouarge et al., 2017). Hoewel de relatieve werkgelegenheid in de laagst betaalde beroepen gegroeid is in de afgelopen 20 jaar, zijn de mediane lonen in reële termen 
onveranderd gebleven. Het lijkt er dan ook op dat er sprake is van een overaanbod aan de onderkant van de arbeidsmarkt, bijvoorbeeld van scholieren en studenten met een bijbaan. De loongroei in de twee hoogste kwintielgroepen was min of meer gelijk aan elkaar (iets minder dan 15\% over de gehele periode), en dit geldt ook voor de middelste kwintielgroep. Dat laatste is dus verassend omdat de werkgelegenheid in die groep in relatieve termen is gedaald. Dit duidt op het bestaan van institutionele barrières, waardoor de achterblijvende vraag naar werkenden in het middensegment zich niet reflecteert in een achterblijvende loonontwikkeling. Ook dit verdient nader onderzoek.

Figuur 11: Relatieve ontwikkeling van bruto uurloon (in reële termen) naar kwintielgroep van beroep

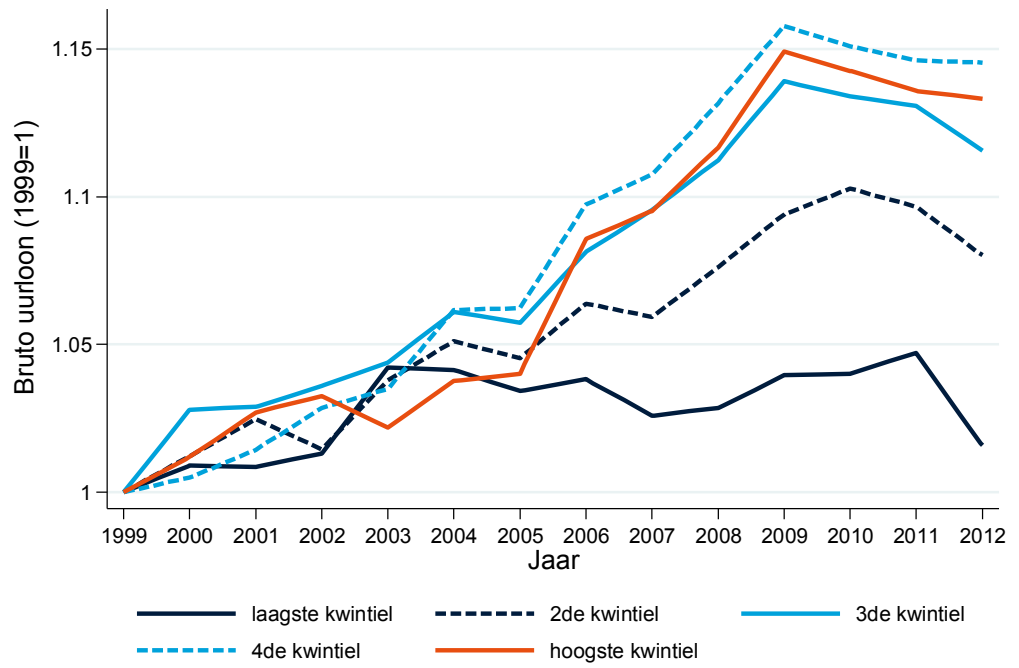

Bron: EBB, SSB 


\section{Studiekeuze en transparantie van de arbeidsmarkt}

De zojuist besproken ontwikkelingen op de arbeidsmarkt zijn bepalend voor de set aan vaardigheden en competenties die nodig zijn voor werkenden om zich staande te houden in het dynamische spel tussen vraag en aanbod. Een leven lang leren, hetzij formeel via cursussen hetzij informeel via leren door te doen, is het motto. Ontwikkelingen in de vraag naar vaardigheden zijn ook bepalend voor de positie van nieuwkomers op de arbeidsmarkt. Wanneer jongeren diplomeren met een set aan vaardigheden waar de markt geen behoefte aan heeft, dan zullen zij moeilijk aan werk kunnen komen.

De beslissing om aan een (vervolg)opleiding te beginnen kan volgens de menselijk kapitaaltheorie worden beschouwd als elke andere vormen van investeringen: een afweging tussen de kosten en de baten van de investering (Becker, 1962). Aan de kostenkant spelen de directe (inschrijfgeld) en indirecte kosten (ofwel opportuniteitskosten; men loopt inkomen uit arbeid mis in de periode waarin men studeert) van scholing. Aan de batenkant kan worden verwacht dat het afronden van een opleiding op een hoog niveau resulteert in een hogere verwachte productiviteit en hoger loon. De arbeidsmarktperspectieven zijn echter niet alleen afhankelijk van het onderwijsniveau (Hartog, 2000), maar ook in toenemende mate van de arbeidsvraag voor de gekozen richting (Altonji et al., 2015). Wanneer de baten van het volgen van een opleiding de kosten overstijgen, dan zal, volgens het menselijk kapitaalmodel, het individu de betreffende opleiding gaan volgen, en anders niet.

In deze kosten-baten afweging spelen de economische voorkeuren -voor tijd en risico- van de studiekiezer een belangrijke rol. De tijdsvoorkeur bepaalt hoe men kijkt tegen de toekomstige kosten en baten van een opleiding. Van iemand die toekomst georiënteerd is, wordt verwacht dat hij/zij de in de toekomst gelegen baten van een opleiding zwaarder zal meewegen dan iemand die louter geïnteresseerd is in de korte termijn (Heckman et al., 2006; Munasinghe en Sicherman, 2006). Studiekiezers met een sterkere voorkeur voor risico wegen de onzekerheid rond hun inkomen in hun loopbaan minder zwaar mee dan 
studiekiezers die risico's schuwen (Bonin et al., 2007; De Paola en Gioia, 2012; Ruder en Van Noy, 2017). Mijn eigen onderzoek met Thomas Dohmen en Ben Kriechel laat inderdaad zien dat jongeren die geduldig (of toekomst georiënteerd) zijn zich sorteren in beroepen met een steiler lopend leeftijdloonprofiel. Jongeren met een sterke risicovoorkeur sorteren zich in beroepen met een groot loonrisico, beroepen die meer conjunctuurgevoelig zijn, en beroepen waar het risico op werkloosheid groter is (Fouarge et al., 2014). Ons onderzoek laat tevens zien dat mensen die in beroepen werken waarvan het loonrisico niet in overeenstemming is met de eigen risicovoorkeur vaker van beroep wisselen en voor beroepen kiezen met een betere fit met hun risicovoorkeur. Wij concluderen dat informatie over loonniveau en loonrisico waardevol is voor een optimale scholings- en beroepskeuze. In een experimenteel onderzoek rond loonrisico van opleidingskeuze komen Ruder en Van Noy (2017) tot dezelfde conclusie.

Naast deze economische voorkeuren spelen natuurlijk een hele reeks andere factoren een rol in de studie en beroepskeuze. Vrontis et al. (2007) onderscheiden vier soorten determinanten: 1) individuele en 2) contextuele determinanten, 3) karakteristieken van de school waar men vandaan komt (bijvoorbeeld compositie van de school en curriculum), en 4) karakteristieken van de school en opleiding waar men instroomt (bijvoorbeeld aanbod van school, locatie, toelatingseisen). Individuele determinanten omvatten naast voorkeuren, persoonlijke eigenschappen (geslacht, sociale herkomst, etc.), cognitieve en psychologische kenmerken (Borghans et al., 2008a), verwachtingen over inkomen (Webbing en Hartog, 2004), en verwachtingen over niet monetaire aspecten van de studiekeuze zoals de slaagkans (Zafar, 2013). Contextuele determinanten hebben betrekking op de economische situatie (Liu et al., 2016), het beleid met betrekking tot toelatingseisen en studiefinanciering, en de rol van externe beïnvloedingsfactoren zoals familie, vrienden, media, en studieadviseurs (Borghans et al., 2015).

De opleidingskeuze is, kortom, een complex proces. Ik wil me in het vervolg van mijn betoog verder richten op drie dimensies -preferenties (wat wil ik?), competenties (wat kan ik?), en arbeidsmarktkansen en loon na het afronden van de opleiding (wat kan ik ermee verdienen?)- die een belangrijke rol spelen in de kosten/baten afweging van de studiekeuze. De focus op preferenties en competenties ligt voor de hand: wanneer men zou kiezen voor een opleiding die 
men niet leuk vindt of intellectueel niet aankan, dan is de kans op uitval groot (Murnane, 2013; Fan en Wolters, 2014). Onderzoek laat tevens zien dat interventies gericht op de ontwikkeling van realistische verwachtingen van jongeren ten aanzien van hun academische capaciteiten de kans op schooluitval vermindert (Goux et al., 2017). Maar waarom doen de arbeidsmarktkansen van een opleiding er toe? Zoals eerder aangegeven gaat het menselijk kapitaalmodel er van uit dat mensen een kosten/baten afweging maken bij hun beslissing om in scholing te investeren. Als er geen banen zijn in de gekozen richting, dan zullen jongeren hun scholingsinvestering niet gemakkelijk terug verdienen: zij zullen moeten wijken naar banen buiten hun domein, of onder hun niveau, lagere lonen moeten accepteren of wellicht werkloos raken. Uit de literatuur weten wij dat wekloosheid een significant negatief effect heeft op het ervaren welzijn (Clark et al., 2008). Onderzoek laat tevens zien dat drie aspecten sterk bepalend zijn voor ervaren welzijn: het hebben van een baan, de financiële situatie, en persoonlijke ontwikkeling en educatie (Fleubaey en Schwandt, 2016). ${ }^{9}$

In een ideale situatie zouden jongeren voor een (vervolg)opleiding kiezen die 'matcht' met hun individuele competenties en preferenties, maar ook goede arbeidsmarktperspectieven biedt. Interesses, capaciteiten, en arbeidsmarktperspectieven (in de vorm van verwacht inkomen) spelen volgens Wiswall en Zafar (2015a) inderdaad een belangrijke rol in de studiekeuze, waarbij interesses de dominante factor is.

Een van mijn belangrijkste taken bij ROA is vorm en sturing geven aan het onderzoeksprogramma Arbeidsmarktdynamiek waarbinnen POA (het Project Onderwijs-Arbeidsmarkt) wordt uitgevoerd. Binnen POA werk ik samen met een enthousiast team aan analyses van de arbeidsmarkt en het samenstellen van arbeidsmarktprognoses naar opleiding, beroep en regio. Als onderdeel van deze prognoses ontwikkelen wij onder andere indicatoren voor de verwachte frictie tussen arbeidsaanbod en arbeidsvraag voor de komende vijf jaar (ROA, 2015). De uitkomsten van het project worden breed verspreid (onder andere via

9 Deze aspecten zijn belangrijker dan gezondheid, maar minder belangrijk dat het gezin/partner. 
Studiekeuze123 en Keuzegids) en dit geeft informatie aan jongeren over het verwachte rendement van hun investering in een opleiding. ${ }^{10}$

Als onderdeel van mijn leerstoel wil ik mij richten op onderzoek naar het effect van dergelijke arbeidsmarktinformatie op de scholingskeuzes van jongeren en volwassenen. Waar ik aan wil bijdragen, is een beter begrip van hoe jongeren hun scholingskeuze maken en of het vergroten van de transparantie van de arbeidsmarkt tot 'betere' keuzes leidt. Wat betere keuzes precies zijn, is lastig te definiëren, maar op microniveau kun je denken aan bijvoorbeeld het hebben van een baan of minder spijt van de scholingskeuze. Op macroniveau kun je denken aan een verbeterde allocatie tussen vraag en aanbod. Op deze nieuwe onderzoekslijn wil ik nu ingaan, door eerst bestaand onderzoek kort te bespreken en vervolgens aan te geven hoe ik aan deze literatuur denk bij te dragen.

\subsection{Literatuur}

In een onlangs gepubliceerd rapport, waar ik hier uit put, heb ik met collega's Annemare Künn-Nelen en Ardi Mommers een review uitgevoerd van de wetenschappelijke literatuur die ingaat op de relatie tussen arbeidsmarktinformatie en de studiekeuze van jongeren (Fouarge et al., 2016). ${ }^{11}$ In deze literatuur -die overigens beperkt in omvang is- vinden wij steun voor het feit dat jongeren inderdaad tot zekere hoogte rationele keuzes maken gebaseerd op een kosten-baten afweging (Kaufman, 2014). Ik bespreek drie soorten onderzoek 1) naar de relatie tussen baankansen en loon en de studiekeuze, 2) (loon) verwachtingen en de studiekeuze, en 3) het causaal effect van arbeidsmarktinformatie op de studiekeuze.

\section{Baankans en loon}

In een deel van de literatuur wordt gekeken naar de relatie tussen feitelijke ontwikkelingen op de arbeidsmarkt (in werkgelegenheid en lonen) en de studiekeuze. Als informatie over de omstandigheden op de arbeidsmarkt aanwezig is (bijvoorbeeld via de media), dan zou je verwachten dat

\footnotetext{
${ }^{10}$ In Fouarge (2015) geef ik een overzicht van de gebruikerskring van POA cijfers. Sinds 2016 makkt ook de Commissie Doelmatigheid Hoger Onderwijs gebruik van POA cijfers bij accreditaties.

${ }^{11}$ Zie ook French en Oreopoulos (2017).
} 
veranderingen in de vraag naar vaardigheden en beroepen van invloed zijn op het aanbod van mensen met een corresponderende opleidingsachtergrond. Aanwijzingen hiervoor worden gevonden in Bardhan et al. (2013) voor de Verenigde Staten: het aanbod reageert zwak op korte termijn veranderingen in loon, en iets sterker op middellange termijn veranderingen in werkgelegenheid. De reactie vertoont een hoge mate van heterogeniteit tussen beroepen en vindt plaats met enige vertraging. Voor Nederland laat ik met Melline Somers zien dat een niet-geanticipeerde stijging van het werkloosheidspercentage voor een studierichting positief samenhangt met de mate waarin gediplomeerden spijt van hun studiekeuze rapporteren (Somers en Fouarge, 2017). Dit suggereert dat het geven van informatie over toekomstige verwachte ontwikkelingen op de arbeidsmarkt de match tussen vraag en aanbod zou kunnen verbeteren.

\section{Loon verwachtingen}

Volgens het menselijk kapitaalmodel bepalen de verwachtingen die jongeren vormen over hun inkomen na afstuderen of zij in onderwijs gaan investeren. De mate waarin deze verwachtingen accuraat zijn (Webbing en Hartog, 2014) of niet (Diaz-Serrano en Nilsson, 2017) verschilt van onderzoek tot onderzoek, maar een reeks studies laat zien dat jongeren meer geneigd zijn om te gaan studeren wanneer zij hogere verwachtingen hebben van de toekomstige salarissen na het afronden van een opleiding (Long et al., 2014; Kaufman, 2014; Schweri en Hartog, 2015). De effecten zij echter niet altijd groot, maar suggereren wel dat het geven van informatie van belang is om goede verwachtingen te kunnen vormen en dat het zou kunnen helpen om beroepen waarvoor een tekort aan personeel is aantrekkelijker te maken (Schweri en Hartog, 2015).

Dat arbeidsmarktinformatie kan bijdragen aan het vormen van betere verwachtingen blijkt ook uit andere studies. Het onderzoek van Arcidiacono et al. (2015) geeft aan dat studenten zouden switchen naar een major die beter past bij hun voorkeuren en capaciteiten wanneer zij betere informatie zouden hebben met betrekking tot de lonen per afgeronde major. Jongeren die bij hun studiekeuze aangeven rekening te houden met arbeidsmarktuitkomsten hebben volgens Hastings et al. (2016) meer realistische inkomensverwachtingen dan jongeren die vooral kiezen op basis van wat zij leuk vinden en de inhoud van de studie. Ze zijn ook eerder geneigd om voor studies te kiezen met een hoger rendement. Conlon (2017) laat zien dat studenten geen realistische 
verwachtingen hebben van salarissen voor afgeronde majors, maar dat het geven van informatie een groot effect heeft op deze verwachtingen. Het is natuurlijk niet realistisch te denken dat de studiekeuze louter gebaseerd zou moeten zijn op inkomens- en arbeidsmarktperspectieven omdat andere motieven zoals plezier hebben in wat men doet een belangrijke rol speelt in de studiekeuze. Toch durf ik de stelling aan dat initiatieven gericht op het verbeteren van de inkomensen arbeidsmarktverwachtingen en op het vergroten van het besef van het belang daarvan, onder (potentiële) studenten zou kunnen leiden tot andere opleidingskeuzes.

\section{Arbeidsmarktinformatie}

Wanneer informatie over de arbeidsmarktkansen van opleidingen beperkt aanwezig of toegankelijk is, of wanneer deze niet goed doordringt tot de gebruiker, dan kan er sprake zijn van suboptimale keuzes. ${ }^{12}$ Loopbaanbegeleiding en transparante arbeidsmarkinformatie kunnen voor meer optimale keuzes zorgen. Wat de loopbaanbegeleiding betreft laat onderzoek van collega's Lex Borghans en Bart Golsteyn zien dat jongeren die op de middelbare school studiebegeleiding (van een decaan, mentor of docent) hebben ontvangen, minder vaak spijt hebben van hun keuze voor een vervolgopleiding (Borghans et al., 2015). Met name jongeren van laagopgeleide ouders lijken baat te hebben bij de studiebegeleiding. Uit het onderzoek valt echter niet op te maken of de begeleiding gericht was of het vinden van een vervolgstudie met de beste fit met de eigen voorkeuren of capaciteiten of dat de arbeidsmarktkansen van die vervolgopleiding ter sprake is gekomen.

Saniter en Siedler (2014) kijken naar het effect van de oprichting van beroepsinformatiecentra (Berufsinformazionszentrum) in Duitsland. Deze centra verschaffen informatie aan jongeren over beroepen, werkgelegenheid, inkomensvooruitzichten, opleidingspaden en dergelijke. Ze zijn willekeurig en sequentieel opgericht in verschillende delen van Duitsland en daar waar een informatiecentrum was, was een bezoek er aan door jongeren verplicht. Deze setting maakt een causale interpretatie van het effect van de oprichting van de informatiecentra op arbeidsmarktuitkomsten mogelijk. De auteurs vinden dat jongeren die in een locatie studeerden waar een informatiecentrum aanwezig

\footnotetext{
12 Informatie over de inhoud van specifieke opleidingsrichtingen blijkt ook niet altijd optimaal en betere informatie hierover kan resulteren in andere keuzes (Fricke et al., 2015).
} 
was, een significant hoger eindniveau behalen en een soepelere transitie naar de arbeidsmarkt maken (grotere kans op een baan en behoud ervan).

De studie door Saniter en Siedler (2014) suggereert dat de beschikbaarheid van arbeidsmarktinformatie helpt, en ik wil me nu kort richten op de vraag of het feitelijk geven van arbeidsmarktinformatie aan jongeren van enige invloed is op hun gemaakte keuze. Ik richt mij op het experimenteel onderzoek op dit terrein. Zo veel studies zijn er niet en een overzicht daarvan is opgenomen in tabel 1. Natuurlijk zijn de eigen preferenties bepalend in de studiekeuze. Het is dan ook niet verassend dat sommige studies nauwelijks tot geen effect vinden van arbeidsmarktinformatie op de studiekeuze (Kerr et al., 2014). Desondanks zijn er ook studies waaruit blijkt dat studenten hun inkomensverwachtingen en studieintentie of -keuze op een rationale manier herzien in het licht van nieuwe informatie (Zafar, 2011). De uitkomstmaten ${ }^{13}$ en de omvang van de effecten verschilt tussen de studies in tabel $1:{ }^{14}$ Hastings et al. (2015) vinden matige tot redelijke effecten, Wiswall \& Zafar (2015a) vinden redelijke tot sterke effecten, en Jensen (2010), en Oreopoulos en Dunn (2013) vinden sterke effecten. Opvallend is ook dat de vatbaarheid voor arbeidsmarktinformatie vaak verschilt naar sociale herkomst. Voor jongeren uit lage sociaal-economische milieus geldt over het algemeen dat zij gevoeliger zijn voor de gegeven arbeidsmarktinformatie (Hoxby en Truner, 2013). Dat zij meer baat hebben bij informatie kan komen door een grotere informatieachterstand (Wiswall \& Zafar, 2015b).

Ook het geven van informatie aan ouders, die in de studiekeuze van hun kinderen een belangrijk rol spelen, kan van invloed zijn. Zo laten Harackiewicz et al. (2012) aan de hand van een veldexperiment zien dat kinderen van ouders die geïnformeerd zijn over het belang van wiskunde en natuurkunde in het dagelijks leven deze vakken op school langer blijven volgen.

\footnotetext{
${ }^{13}$ In de studies is gekeken naar 1) het ontwikkelen van hogere verwachtingen over de opbrengsten van onderwijs, 2) een sterkere intentie om in het onderwijs te blijven, 3) vaker voor vervolgonderwijs kiezen, 4) specifieke opleidingen kiezen met goede perspectieven.

${ }^{14}$ De verschillen in bevindingen tussen de experimentele studies kunnen liggen aan de onderliggende verschillen 1) tussen landen waarin de studies zijn uitgevoerd, 2) in de operationaliseringen van het concept 'studiekeuze' (sommige studies kijken naar intenties, andere naar daadwerkelijke inschrijving voor een opleiding), 3) in het soort informatie dat gegeven is (over loon, kansen op werk, of ook andere informatie), en 4) in de wijze waarop de arbeidsmarktinformatie is gegeven (persoonlijke voorlichting, video, of informatie via de computer).
} 
Het aantal causale studies naar het effect van arbeidsmarktinformatie in de studiekeuze is beperkt en een aantal vragen blijft open: Voor welk type informatie zijn jongeren het meest receptief? Op welk moment tijdens het studiekeuzeproces is het geven van informatie het meest effectief? Welke methode van informatieoverdracht is het meest succesvol? Deze vraagstukken, in combinatie met het feit dat er geen Nederlandse (effect)studies voorradig zijn, maakt vervolgonderzoek noodzakelijk, bij voorkeur in een experimentele setting. Ik verheug me op de samenwerking met collega Robert Dur op dit terrein.

Tabel 1: Experimentele studies naar het effect van verschaffen van (arbeidsmarkt)informatie op de studiekeuze

\begin{tabular}{|c|c|c|c|c|}
\hline Bron & Onderzoeksvraag & Data & Interventie & Bevinding \\
\hline $\begin{array}{l}\text { Jensen } \\
(2010)\end{array}$ & \begin{tabular}{|l|} 
In hoeverre spelen \\
toekomstige \\
opbrengsten ('perceived \\
returns') een rol bij \\
keuze van scholieren \\
voor vervolgonderwijs?
\end{tabular} & $\begin{array}{l}\text { Wie: } 2.250 \text { jongens uit de } \\
\text { Dominicaanse Republiek, } \\
\text { aan einde van middelbare } \\
\text { schoolperiode. } \\
\text { Observatie: Panelstudie. } \\
\text { Enquêtes onder jongeren: } \\
\text { aan einde middelbare } \\
\text { school (o.a. } \\
\text { inkomensverwachtingen); } \\
\text { in het volgende jaar } \\
\text { (gemaakte } \\
\text { opleidingskeuze); en } \\
\text { enkele jaren later } \\
\text { (behaalde } \\
\text { opleidingsresultaat). }\end{array}$ & \begin{tabular}{|l|} 
Een deel kreeg in de \\
vragenlijst een \\
informatietekst te zien \\
waarin de gemiddelde \\
inkomens voor 30-40 \\
jarigen (o.b.v. \\
enquêtedata) \\
gepresenteerd werden, \\
gespecificeerd naar \\
opleidingsniveau (30-40 \\
jarigen met alleen \\
basisschool; met alleen \\
middelbare school; of met \\
hoger onderwijs).
\end{tabular} & $\begin{array}{l}\text { Effect: sterk } \\
\text { Toelichting: Jongeren die de } \\
\text { interventie kregen, kiezen } \\
4 \% \text { vaker voor } \\
\text { vervolgonderwijs en } \\
\text { volgen gemiddeld } 0,2 \text { jaar } \\
\text { lánger onderwijs dan de } \\
\text { andere jongeren. Onder de } \\
\text { 'armste' jongeren werd } \\
\text { echter nauwelijks effect } \\
\text { gevonden. }\end{array}$ \\
\hline $\begin{array}{l}\text { McGuigan, } \\
\text { McNally \& } \\
\text { Wyness } \\
(2012)\end{array}$ & $\begin{array}{l}\text { Wat is de invloed van } \\
\text { een } \\
\text { 'informatiecampagne' } \\
\text { over economische en } \\
\text { financiële aspecten van } \\
\text { onderwijskeuzes (kosten } \\
\text { en opbrengsten), op de } \\
\text { onderwijsaspiraties van } \\
\text { jongeren? }\end{array}$ & $\begin{array}{l}\text { Wie: } 6.615 \text { Engelse 14- en } \\
\text { 15-jarige scholieren, } \\
\text { d.w.z. kort voor het } \\
\text { eindigen van de } \\
\text { leerplicht. } \\
\text { Observatie: } 2 \text { vragenlijsten } \\
\text { naar onderwijskennis } \\
\text { (kosten en baten van } \\
\text { onderwijs) en -aspiraties } \\
\text { (toekomstige intenties, } \\
\text { bijv. van school afgaan). } \\
\text { Tijd tussen vragenlijsten } \\
\text { 8-12 weken. }\end{array}$ & $\begin{array}{l}\text { Een deel van de scholieren } \\
\text { onderging de } \\
\text { 'informatiecampagne' met } \\
\text { economische (o.a. } \\
\text { verwachte lonen, } \\
\text { baankansen) en financiële } \\
\text { informatie (studiekosten, } \\
\text { beurzen, leningen etc.). } \\
\text { Scholieren kregen } \\
\text { toegang tot een website } \\
\text { en ontvingen een } \\
\text { informatieflyer, hun } \\
\text { leraren kregen } \\
\text { lesmateriaal (video en een } \\
\text { presentatie). }\end{array}$ & \begin{tabular}{|l|} 
Effect: redelijk \\
Toelichting: De campagne \\
heeft een positief effect op \\
de intentie van jongeren \\
om in het onderwijs te \\
blijven ( $3 \%$ grotere kans), \\
maar heeft geen invloed op \\
de intentie om uiteindelijk \\
naar de universiteit te \\
willen.
\end{tabular} \\
\hline
\end{tabular}




\begin{tabular}{|c|c|c|c|c|}
\hline \begin{tabular}{|l|} 
Oreopoulos \\
\& Dunn \\
$(2013)$
\end{tabular} & $\begin{array}{l}\text { Kan online informatie } \\
\text { over het hoger } \\
\text { onderwijs de interesses } \\
\text { voor en verwachtingen } \\
\text { over vervolgonderwijs } \\
\text { onder kansarme } \\
\text { jongeren } \\
\text { ('disadvantaged } \\
\text { students') beïnvloeden? }\end{array}$ & $\begin{array}{l}\text { Wie: } 1.616 \text { Canadese } \\
\text { middelbare scholieren uit } \\
\text { buurten met lage } \\
\text { inkomens. } \\
\text { Observatie: } 2 \text { surveys (met } \\
3 \text { weken tussen beide). In } \\
\text { vragenlijst } 1 \text { o.a. } \\
\text { demografische } \\
\text { kenmerken en kennis van } \\
\text { studenten over } \\
\text { vervolgonderwijs, In } \\
\text { vragenlijst 2: o.a. } \\
\text { verwachte opbrengsten } \\
\text { van vervolg onderwijs en } \\
\text { onderwijsintenties. }\end{array}$ & $\begin{array}{l}\text { Een deel van de scholieren } \\
\text { kregen in de vragenlijst } \\
\text { een video van enkele } \\
\text { minuten te zien. Enerzijds } \\
\text { nuanceerde de video } \\
\text { studiekosten en } \\
\text { benadrukte het de } \\
\text { mogelijkheden voor } \\
\text { financiële ondersteuning. } \\
\text { Anderzijds werden } \\
\text { inkomens gepresenteerd } \\
\text { van 35-jarigen met: een } \\
\text { middelbareschooldiploma; } \\
\text { een 2-jarig 'college' } \\
\text { diploma; een 4-jarig } \\
\text { 'college' diploma; en een } \\
\text { 4-jarig } \\
\text { universiteitsdiploma. }\end{array}$ & $\begin{array}{l}\text { Effect: sterk } \\
\text { Toelichting: Jongeren die de } \\
\text { video gezien hadden, } \\
\text { hebben o.a. hogere } \\
\text { verwachtingen van de } \\
\text { opbrengsten van } \\
\text { vervolgonderwijs en geven } \\
\text { vaker aan dat ze in ieder } \\
\text { geval een 'college' diploma } \\
\text { willen behalen ( } 3,5 \% \text { vaker } \\
\text { dan controlegroep). De } \\
\text { effecten zijn het sterkst } \\
\text { onder jongeren die } \\
\text { aanvankelijk erg twijfelden } \\
\text { over vervolgonderwijs. }\end{array}$ \\
\hline \begin{tabular}{|l|} 
Kerr, \\
Pekkarinen, \\
Sarvimäki \& \\
Uusitalo \\
(2014)
\end{tabular} & $\begin{array}{l}\text { Heeft het verschaffen } \\
\text { van gedetailleerde } \\
\text { arbeidsmarktinformatie } \\
\text { een effect op de } \\
\text { aanmeldingen (en } \\
\text { acceptatie) van } \\
\text { jongeren in het } \\
\text { vervolgonderwijs? }\end{array}$ & $\begin{array}{l}\text { Wie: Ongeveer } 3.500 \\
\text { Finse scholieren aan } \\
\text { einde van middelbare } \\
\text { schoolperiode. } \\
\text { Observatie: Gebruik van } \\
\text { registratiedata over } \\
\text { inschrijvingen in } \\
\text { vervolgonderwijs. }\end{array}$ & $\begin{array}{l}\text { Alle scholieren in het } \\
\text { onderzoek kregen op } \\
\text { school een verplichte 45- } \\
\text { minuten durende } \\
\text { voorlichting van de } \\
\text { loopbaanbegeleider over } \\
\text { vooruitzichten op de } \\
\text { arbeidsmarkt (lonen, } \\
\text { baankansen) op basis van } \\
\text { afgestudeerdengegevens } \\
\text { in meer dan } 60 \\
\text { opleidingen. De } \\
\text { controlegroep bestaat in } \\
\text { deze studie uit de totale } \\
\text { overige populatie van } \\
\text { studenten. }\end{array}$ & $\begin{array}{l}\text { Effect: nauwelijks } \\
\text { Toelichting: Er zijn (vrijwel) } \\
\text { geen verschillen in } \\
\text { aanmeldingen en } \\
\text { inschrijvingen voor } \\
\text { opleidingsrichtingen } \\
\text { tussen de interventiegroep } \\
\text { en de controlegroep. } \\
\text { Alleen jongeren uit de } \\
\text { interventiegroep met een } \\
\text { lagere sociaal-economische } \\
\text { status waren iets meer } \\
\text { geneigd zich aan te melden } \\
\text { voor opleidingen waar de } \\
\text { inkomens hoger liggen. } \\
\text { Ook hier zijn echter geen } \\
\text { verschillen in het } \\
\text { daadwerkelijk } \\
\text { ingeschreven staan. }\end{array}$ \\
\hline \begin{tabular}{|l|} 
Bleemer \& \\
Zafar (2015)
\end{tabular} & $\begin{array}{l}\text { Heeft } \\
\text { informatieverschaffing } \\
\text { over opbrengsten en } \\
\text { kosten van } \\
\text { vervolgonderwijs } \\
\text { invloed op } \\
\text { verwachtingen van } \\
\text { ouders over het volgen } \\
\text { van vervolgonderwijs } \\
\text { door hun kinderen? }\end{array}$ & $\begin{array}{l}\text { Wie: } 1.146 \text { Amerikaanse } \\
\text { 'gezinshoofden'. } \\
\text { Observatie: } 2 \\
\text { vragenlijsten, o.a. vragen } \\
\text { over inschattingen van } \\
\text { inkomens (indien iemand } \\
\text { wel/geen } \\
\text { vervolgonderwijs heeft), } \\
\text { studiekosten en kans dat } \\
\text { kind naar 'college' gaat. }\end{array}$ & $\begin{array}{l}\text { In eerste vragenlijst } \\
\text { driedeling in } \\
\text { respondenten. Eerste } \\
\text { groep kreeg informatie te } \\
\text { zien over opbrengsten van } \\
\text { studeren; tweede groep } \\
\text { over kosten van studeren; } \\
\text { en derde groep kreeg } \\
\text { geen aanvullende } \\
\text { informatie (controlegroep) }\end{array}$ & $\begin{array}{l}\text { Effect: redelijk } \\
\text { Toelichting: respondenten } \\
\text { die opbrengsteninformatie } \\
\text { kregen, hebben sterkere } \\
\text { intentie dat hun kind } \\
\text { vervolgonderwijs gaat } \\
\text { volgen }(0,2 \\
\text { standaarddeviatie meer). } \\
\text { Dit effect is het sterkst bij } \\
\text { jongeren met lage sociaal- } \\
\text { economische status. Bij } \\
\text { respondenten in de } \\
\text { kosteninformatie-groep is } \\
\text { geen effect op de intentie } \\
\text { waarneembaar. }\end{array}$ \\
\hline
\end{tabular}




\begin{tabular}{|c|c|c|c|c|}
\hline \begin{tabular}{|l|} 
Hastings, \\
Neilson \& \\
Zimmerman \\
$(2015)$
\end{tabular} & \begin{tabular}{|l|} 
Wat is de invloed van \\
informatie over \\
arbeidsmarktuitkomsten \\
op de keuze van \\
jongeren om te gaan \\
studeren, c.q. op de \\
keuze welke 'major' ze \\
willen volgen?
\end{tabular} & $\begin{array}{l}\text { Wie: } 49.166 \text { Chileense } \\
\text { jongeren aan einde } \\
\text { middelbare } \\
\text { schoolperiode. } \\
\text { Observatie: Vragenlijst } \\
\text { aan einde middelbare } \\
\text { schoolperiode o.a. naar } \\
\text { voorkeuren voor } \\
\text { instellingen en } \\
\text { opleidingen. In later } \\
\text { stadium observatie van } \\
\text { feitelijke } \\
\text { inschrijvingsgegevens } \\
\text { van deze jongeren. }\end{array}$ & $\begin{array}{l}\text { Een deel van de } \\
\text { deelnemers kreeg via de } \\
\text { vragenlijst toegang tot } \\
\text { een doorzoekbare online } \\
\text { database met } \\
\text { registratiegegevens over } \\
\text { afgestudeerden } \\
\text { (inkomsten, gemaakte } \\
\text { studiekosten etc.). }\end{array}$ & $\begin{array}{l}\text { Effect: matig/redelijk } \\
\text { Toelichting: De interventie } \\
\text { heeft geen effect op } \\
\text { wel/niet ingeschreven } \\
\text { staan in vervolgonderwijs. } \\
\text { Voor jongeren met een } \\
\text { lage sociaal-economische } \\
\text { status heeft de interventie } \\
\text { echter wel effect. Zij kiezen } \\
\text { vaker voor opleidingen me } \\
\text { hogere inkomens. }\end{array}$ \\
\hline $\begin{array}{l}\text { Wiswall \& } \\
\text { Zafar } \\
(2015 a)\end{array}$ & \begin{tabular}{|l|} 
In hoeverre passen \\
studenten hun \\
verwachtingen over \\
inkomens van majors \\
aan op basis van \\
arbeidsmarktinformatie? \\
Wat betekent dit voor \\
studiekeuze?
\end{tabular} & $\begin{array}{l}\text { Wie: } 488 \text { Amerikaanse } \\
\text { eerste-, tweede- of } \\
\text { derdejaarsstudenten. } \\
\text { Observatie: enquête } \\
\text { waarin meermaals (voor } \\
\text { en na de interventie) o.a. } \\
\text { inkomensverwachtingen } \\
\text { voor diverse majors } \\
\text { werden bevraagd. }\end{array}$ & $\begin{array}{l}\text { Een deel van de studenten } \\
\text { kreeg in de vragenlijst } \\
\text { feitelijke informatie te zien } \\
\text { over afgestudeerden naar } \\
\text { major, bijvoorbeeld } \\
\text { gemiddelde inkomens } \\
\text { naar opleidingsrichting en } \\
\text { het gemiddelde } \\
\text { Amerikaanse inkomen. }\end{array}$ & $\begin{array}{l}\text { Effect: redelijk/sterk } \\
\text { Toelichting: } \\
\text { De meeste studenten } \\
\text { passen } \\
\text { inkomensverwachtingen } \\
\text { aan op de informatie. Van } \\
5 \% \text { bijstelling naar } \\
\text { beneden voor de diploma } \\
\text { 'Economie' tot } 55 \% \\
\text { bijstelling naar boven voor } \\
\text { 'geen diploma'. } \\
\text { Inkomensverwachtingen } \\
\text { en studiekeuze zijn volgens } \\
\text { auteurs verweven en dus } \\
\text { heeft informatie volgens } \\
\text { hen impact. }\end{array}$ \\
\hline \begin{tabular}{|l} 
Bonilla, \\
Bottan \& \\
Ham (2016)
\end{tabular} & $\begin{array}{l}\text { Heeft het verschaffen } \\
\text { van informatie over } \\
\text { kosten en opbrengsten } \\
\text { van vervolgonderwijs } \\
\text { invloed op de } \\
\text { onderwijskeuzes van } \\
\text { jongeren? }\end{array}$ & $\begin{array}{l}\text { Wie: Bijna } 6.000 \\
\text { Colombiaanse jongeren } \\
\text { aan einde van middelbare } \\
\text { schoolperiode. } \\
\text { Observatie: registratiedata } \\
\text { o.a. over examenscores } \\
\text { en inschrijvingen in } \\
\text { vervolgonderwijs. }\end{array}$ & $\begin{array}{l}\text { Een deel van de jongeren } \\
\text { kreeg op school een } \\
\text { presentatie te horen van } \\
\text { een recent afgestudeerde } \\
\text { uit de regio. Hier werd } \\
\text { informatie verschaft over } \\
\text { de opbrengsten } \\
\text { ('monetary returns') } \\
\text { gespecificeerd naar } \\
\text { instelling en opleiding, en } \\
\text { over mogelijkheden voor } \\
\text { studiefinanciering. }\end{array}$ & $\begin{array}{l}\text { Effect: redelijk } \\
\text { Toelichting: De interventie } \\
\text { heeft geen invloed op het } \\
\text { wel/niet ingeschreven } \\
\text { staan in vervolgonderwijs. } \\
\text { Wel staan ze vaker } \\
\text { ingeschreven op betere } \\
\text { instellingen ( } 2 \% \text { grotere } \\
\text { kans op 'top-10 instelling) } \\
\text { en bij opleidingen die } \\
\text { selectiever zijn ( } 4 \% \text { grotere } \\
\text { kans op een 'academisch } \\
\text { programma'). }\end{array}$ \\
\hline
\end{tabular}

Bron: Fouarge et al. (2016: 23-25)

\subsection{Onderzoek}

Als voorproefje op wat komen gaat wil ik alvast verslag doen van enkele bevindingen uit eigen koker gebaseerd op een eigen survey gehouden onder 
mbo-gediplomeerden. De survey was gericht op de door hen gebruikte informatiebronnen bij het maken van hun eigen opleidingskeuze, met een nadruk op de mate waarin deze gediplomeerden gebruik hebben gemaakt van arbeidsmarktinformatie bij het maken van die keuze. ${ }^{15}$

\section{Informatiekanalen}

Figuur 12 laat zien dat voorlichtingsdagen door mbo-opleidingen en gesprekken met familie de meest gebruikte informatiekanalen zijn. Voor deze informatiekanalen en voor gesprekken met docent/decaan/mentor ${ }^{16}$ hebben wij vervolgens gevraagd wat men hiervan geleerd heeft met betrekking tot eigen interesses, capaciteiten, en arbeidsmarktperspectieven van de opleiding. De resultaten zijn samengevat in figuur 13.

Figuur 12: Gebruikte informatiekanalen van mbo'ers bij opleidingskeuze

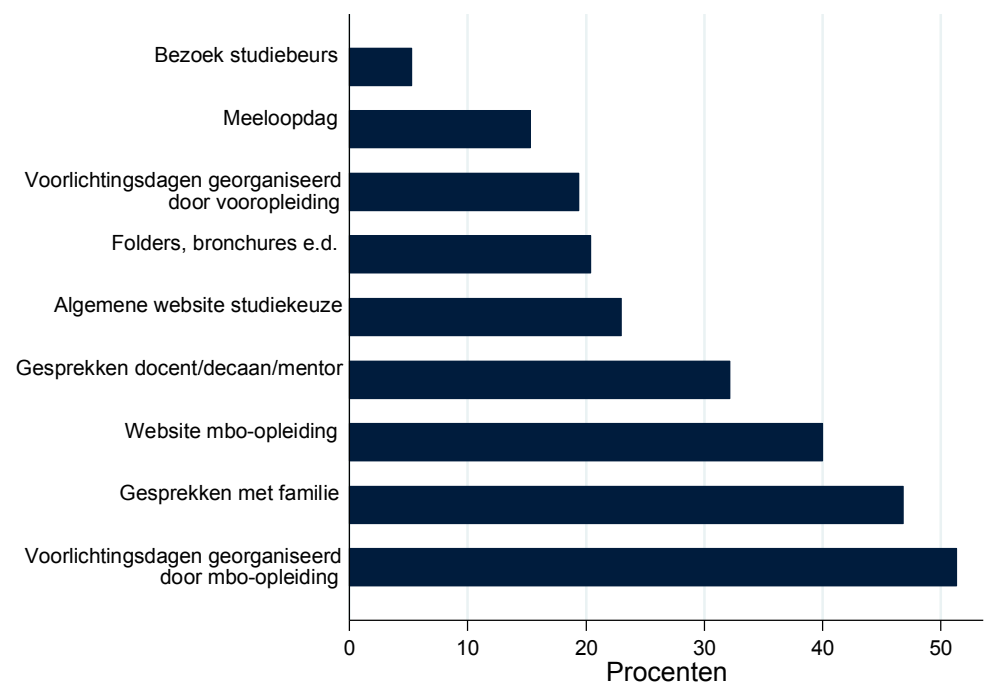

Bron: ROA, Transparante arbeidsmarkt 2016

\footnotetext{
${ }^{15}$ De survey is afgenomen als een supplement op de 2015 BVE monitor gehouden in november 2016. Ik richt me hier op mbo-bol-gediplomeerden uit de niveaus 2, 3, en 4 die maximaal 25 jaar oud zijn.

${ }^{16}$ Omdat gebleken is dat dergelijke gesprekken de kans verkleint dat men spijt heeft van de studiekeuze (Borghans et al., 2015).
} 
Figuur 13 laat zien dat het bezoeken van voorlichtingsdagen en het voeren van gesprekken met familie en docenten vooral helpen bij het verkrijgen van een goed beeld van wat men leuk vind. Gesprekken helpen ook ontdekken waar men goed in is. Gesprekken met familie zijn ook van invloed op de studiekeuze, meer zo dan gesprekken met docenten of het bezoeken van voorlichtingsdagen. Nog geen $50 \%$ is het (helemaal) eens met de stelling dat voorlichtingsdagen en gesprekken een beter beeld hebben gegeven van de carrièremogelijkheden van opleidingen. Daar valt winst te behalen zou ik denken.

Figuur 13: Wat men haalt uit voorlichtingsdagen en gesprekken met familie en docenten

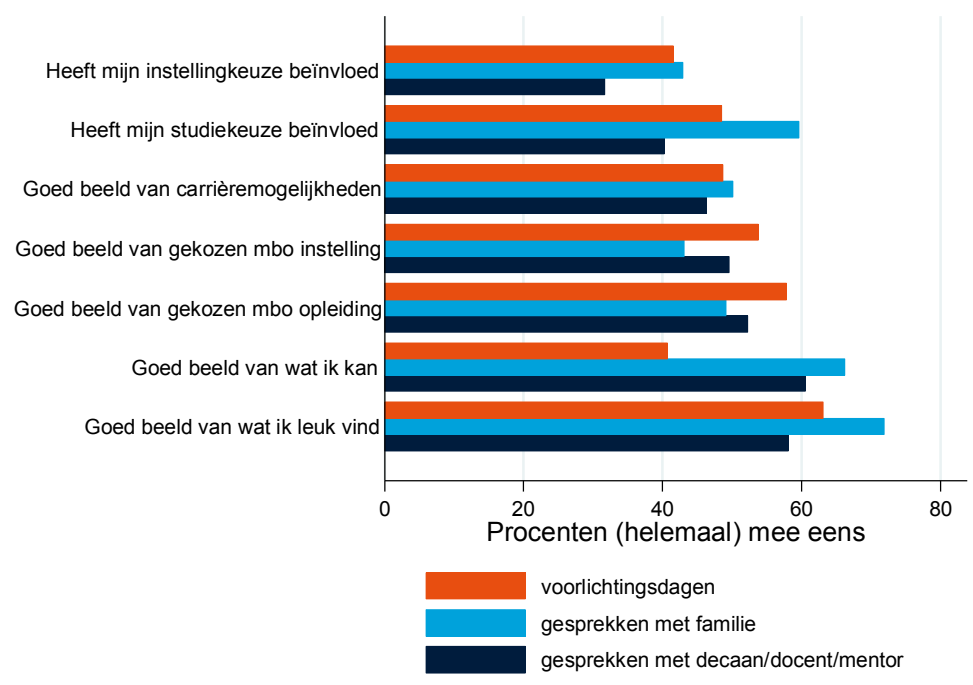

Bron: ROA, Transparante arbeidsmarkt 2016

Wij hebben ook direct gevraagd aan deze recent gediplomeerden uit het mbo in welke mate zij wat zij leuk vinden, waar zij goed in zijn, en carrièremogelijkheden hebben meegenomen bij het maken van hun opleidingskeuze. Niet verassend kiezen jongeren vooral op basis van wat zij leuk vinden, en carrièremogelijkheden van de gekozen opleiding komen op de laatste plaats (figuur 14). Wat interessant 
is, is dat uit regressieanalyses ${ }^{17}$ blijkt dat naarmate jongeren in sterkere mate carrièreperspectieven hebben laten meewegen in hun keuze, zij een grotere kans op werk hebben, en dat het vaker werk betreft in de eigen richting en op het eigen niveau. Ze zijn ook vaker tevreden met hun functie/beroep en hebben minder spijt van de studiekeuze. De relatie met het loon is ook positief, maar niet significant en dit komt vooral doordat deze jongeren meer uren werken.

Figuur 14: Aspecten die meegewogen zijn bij de opleidingskeuze

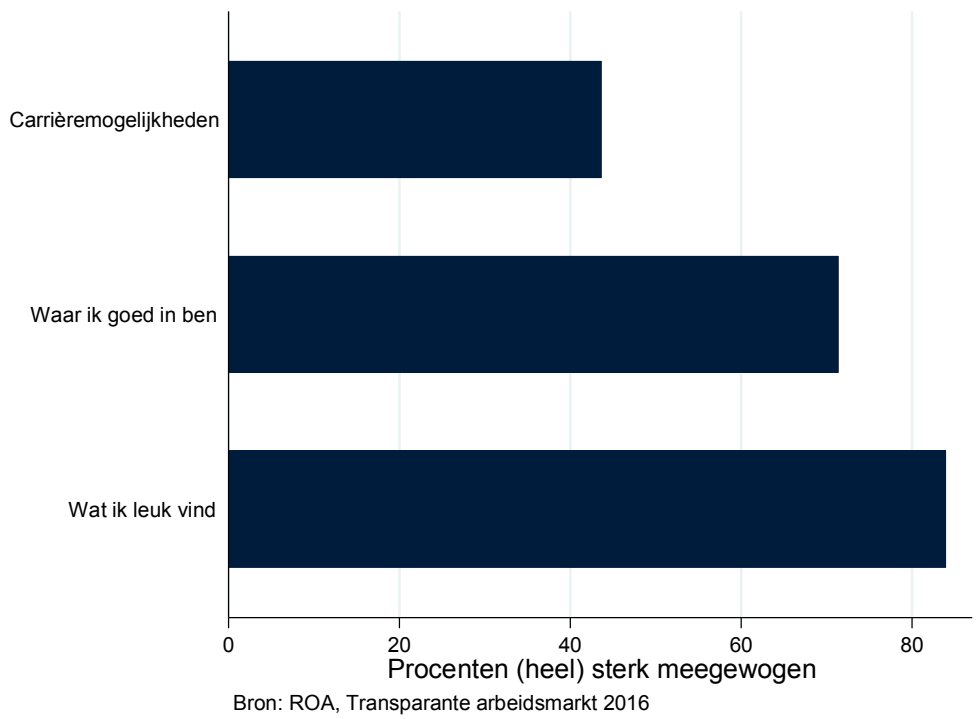

\section{Keuze-experiment}

Het is lastig om met retrospectieve vragen zoals hierboven geschetst de afruil die jongeren maken tussen interesses, capaciteiten, en arbeidsmarktperspectieven goed te meten. In onze survey hebben wij een keuze-experiment (vignet) opgenomen waarin gevraagd is een keuze te maken tussen twee verschillende mbo-opleidingen ( $\mathrm{A}$ of $\mathrm{B}$ ) die van elkaar verschillen op een aantal relevante attributen met betrekking tot de mate waarin de opleiding passend is bij

\footnotetext{
${ }^{17}$ Waarbij gecontroleerd is voor geslacht, leeftijd, opleidingsrichting en mate waarin zij wat ze leuk vinden en waar ze goed in zijn hebben mee laten wegen in hun opleidingskeuze.
} 
interesses en capaciteiten, en arbeidsmarktuitkomsten van de opleidingen. ${ }^{18}$ De attributen en de gerandomiseerde waarde ervan zijn als volgt:

Passende opleiding:

- studie passend bij capaciteiten: slecht / gemiddeld / goed.

- studie passend bij interesses: slecht / gemiddeld / goed.

Arbeidsmarktkenmerken: ${ }^{19}$

- kans op werk na afstuderen: slecht / gemiddeld / goed.

- doorgroeimogelijkheden: slecht / gemiddeld / goed.

Omdat de respondenten van de mbo-monitor zelf hun studiekeuze al achter de rug hebben, was het niet vanzelfsprekend om ze te vragen de keuze voor zichzelf te maken. Wij hebben ze gevraagd een vmbo'er te adviseren welke opleiding te gaan volgen, waarbij jongens gevraagd is een jongen en meisjes een meisje te adviseren. Om het realistisch te houden is hierbij gekozen voor veel voorkomende namen (Thomas en Laura) in de geboortecohort van de mbogediplomeerden. Respondenten zijn vijf keer gevraagd om een afweging te maken tussen twee opleidingen, waarbij de volgorde van de relevante attributen tussen respondenten gerandomiseerd is. Een voorbeeld van een dergelijk vignet is opgenomen in figuur 15 .

\footnotetext{
${ }^{18}$ Het vignet bevatte ook twee schoolkenmerken: reistijd naar school (minder dan 15 minuten / 30 minuten / 60 minuten / meer dan 60 minuten) en kwaliteit van de stagebegeleiding (slecht / gemiddeld / goed). Voor een verantwoording van vignetstudies, zie Louviere et al. (2000).

${ }^{19} \mathrm{Er}$ is hierbij gekozen voor kwalificaties van de arbeidsmarktkansen vergelijkbaar met die zoals gebruikt binnen het POA en zoals gepubliceerd op Studiekeuze123 en in de Keuzegids.
} 
Figuur 15: Voorbeeld vignet

Q9.1. We willen je voorstellen aan Thomas, hij zit in zijn laatste jaar van het vmbo. Daarna wil hij een vervolgopleiding gaan volgen in het mbo.

In de volgende vif vagen leggen we steeds twee mbo-opleidingen naast elkaar. De mbo-opleidingen verschillen op een zestal kenmerken van elkaar: de mate waarin de studie passend is bij zijn capaciteiten en interesses, kans op werk na afstuderen, de doorgroeimogelijkheden, de reistijd naar school en de kwaliteit van stagebegeleiding. Andere niet genoemde kenmerken zijn hetzelfde voor de beide mbo-opleidingen.

Q9.2. Keuze 1 van 5:

Welke van de twee mbo-opleidingen zou jij Thomas adviseren?

\begin{tabular}{|l|c|c|}
\hline Kenmerk mbo-opleiding & mbo-opleiding A & mbo-opleiding B \\
\hline Passend bij capaciteiten & goed & slecht \\
\hline Passend bij interesses & gemiddeld & goed \\
\hline Kans op werk na afstuderen & hoog & hoog \\
\hline Doorgroeimogelijkheden & goed & goed \\
\hline Reistijd naar school (enkele reis) & meer dan 60 minuten & 30 minuten \\
\hline Kwaliteit van stagebegeleiding & slecht & slecht \\
\hline
\end{tabular}

A B

$\odot \mathrm{C}$

Als wij de gekozen opleiding relateren aan de kenmerken van die opleiding, kunnen wij een aantal conclusies trekken (figuur 16). ${ }^{20}$ Ten eerste, alle door ons genoemde kenmerken blijken relevant voor de opleidingskeuze. Ten tweede, de mate waarin de opleiding passend is bij de interesses heeft het grootst effect op het wel/niet kiezen van de opleiding. De kans dat de opleiding wordt gekozen is ongeveer 32\%-punten hoger wanneer de opleiding een goede fit heeft met de interesses dan wanneer de fit slecht is. Ten derde, in deze setting, waarin de arbeidsmarktkansen van opleidingen expliciet benoemd worden, blijken jongeren sterk te reageren op deze informatie in hun keuze. Het effect van arbeidsmarktkenmerken is in omvang vergelijkbaar met dat van de mate waarin de opleiding passend is bij de capaciteiten. Ten slotte, het signaal 'slecht' (of het nu gaat op slecht passend bij interesses, of slechte arbeidsmarktkansen) heeft een groter effect op het niet kiezen voor een opleiding dan het tegenovergestelde boodschap 'goed' op de kans dat de opleiding wel gekozen wordt. Men moet hier wel voorzichtig blijven bij deze interpretatie omdat het niet duidelijk is of respondenten de signalen slecht, gemiddeld en goed inderdaad zien als onderdeel van een continuüm, maar de bevinding is in lijn met onderzoek van Pistolesi (2017) waar uit blijkt dat studenten gevoeliger zijn voor negatieve feedback bij hun keuze voor een major.

${ }^{20}$ De figuur geeft de marginale effecten weer van een probit model voor opleidingskeuze (1 indien gekozen), met de kenmerken van de opleidingen als regressoren. 
Figuur 16: Verschil in kans dat opleiding gekozen wordt, naar kenmerken van opleiding

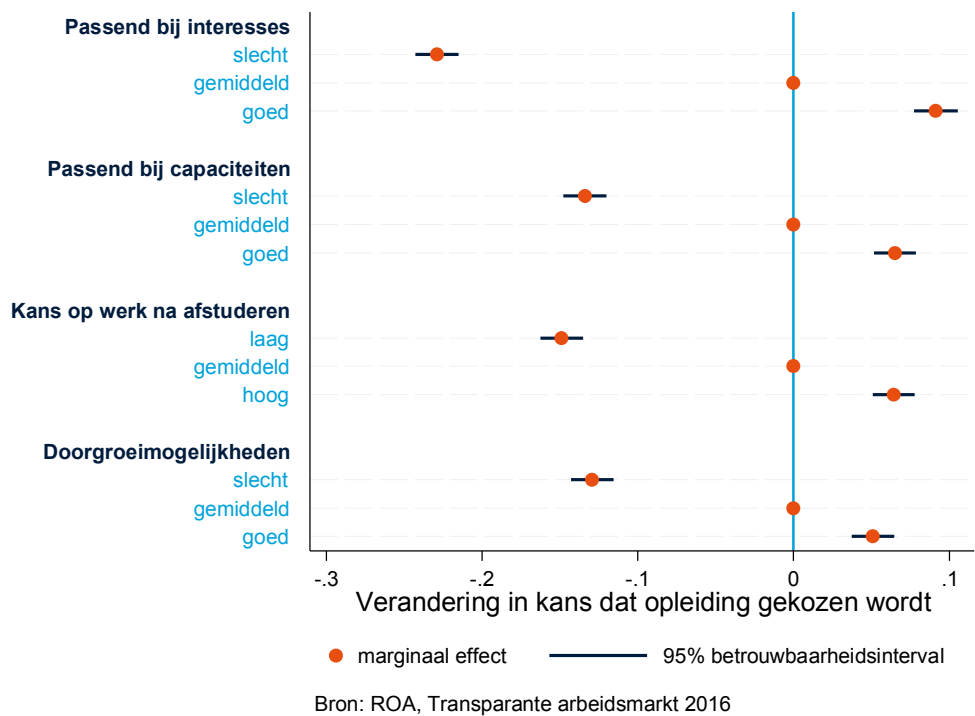

Dergelijke data maakt het ook mogelijk om de afruil die jongeren maken tussen kenmerken van opleidingen te kwantificeren. Figuur 17 laat zo een afruil zien tussen de mate waarin de opleiding passend is bij de interesses (op de horizontale as) en de kans op werk na diplomering (de lijnen in de figuur). Voor de figuur heb ik er voor gekozen om de verschillen in kansen te laten zien ten opzichte van de 'slechtste' optie: een opleiding met een slechte fit met interesses en ook nog eens een slechte kans op werk na het behalen van het diploma. ${ }^{21}$ De figuur laat twee belangrijke zaken zien. Ten eerste, bij een opleiding met een goede fit is de kans 16\%-punten hoger dat deze wordt verkozen wanneer de kansen op werk gemiddeld zijn vergeleken met slecht (verschil tussen punten $A$ en B) en zelfs 22\%-punten hoger bij goede perspectieven (verschil tussen punten A en C). Al deze verschillen zijn significant. Ten tweede laat het zien dat de kans dat een opleiding gekozen wordt met een gemiddelde fit met interesses, en

\footnotetext{
${ }^{21}$ Ik zet de kans dat zo een opleiding gekozen wordt op 0 . De figuur laat de verschillen in marginale effecten zien voor de kans dat een opleiding wordt gekozen, waarbij de fit met interesses en kans op werk na afstuderen zijn geïnteracteerd en de overige kenmerken op gemiddeld staan (de reistijd op 30 minuten).
} 
goede of zelfs gemiddelde perspectieven op werk, significant hoger is dan een opleiding die weliswaar een goede fit biedt met interesses, maar geen goede perspectieven op werk heeft (punten $D$ en $E$ zijn significant hoger gelegen dan punt A. Dit suggereert dat jongeren mogelijk zouden switchen van opleidingskeuze -van de opleiding met de beste fit met interesses naar de opleiding met de een na beste fit- wanneer zij informatie krijgen over de verschillen in arbeidsmarktkansen van opleidingen.

Figuur 17: Verschil in kans dat opleiding wordt gekozen

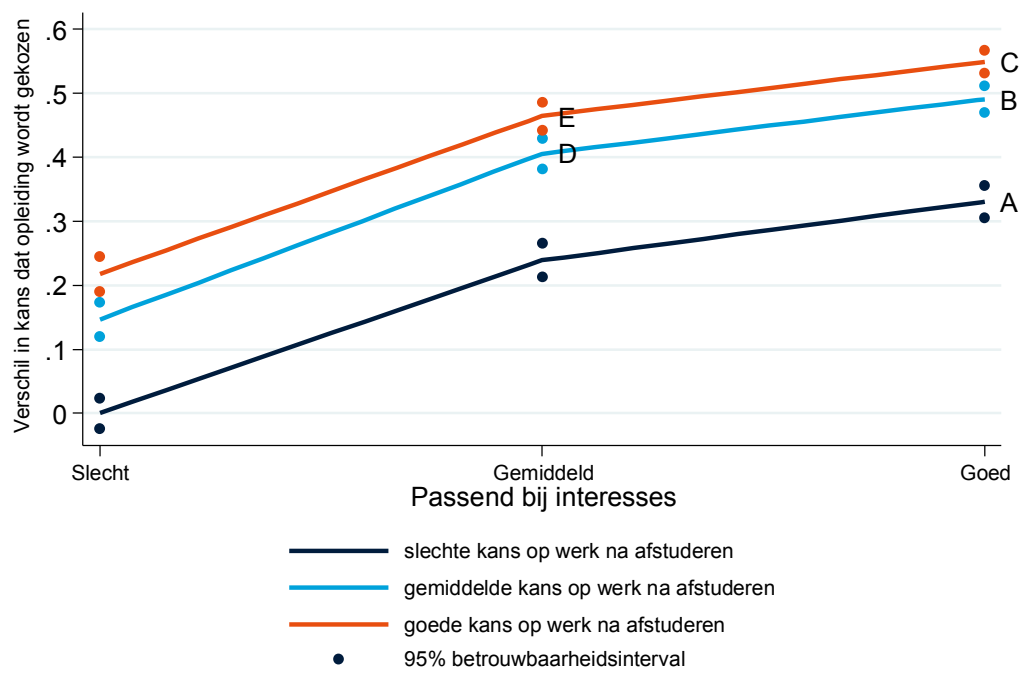

Bron: ROA, Transparante arbeidsmarkt 2016

\section{Implicaties voor beleid}

De vraag naar vaardigheden verandert voortdurend, en het is van belang dat deze dynamiek goed in beeld wordt gebracht. Niet alleen in historische reeksen, maar ook prospectief, met een oog gericht op de toekomst. Dit belang speelt in het bijzonder voor studiekiezers omdat zij immers voor een belangrijke beslissing staan, namelijk: in welke studie zal ik mijn tijd en geld investeren, en wat haal ik er straks uit? 
In beleid en media is de polariseringsdiscussie afgelopen jaren breed uitgemeten. Daarbij zijn vaak ten onrechte twee simplificaties gemaakt. Ten eerste, zijn conclusies uit onderzoek over de relatieve krimp van beroepen in het middensegment van de loonverdeling geïnterpreteerd als absolute krimp van de werkgelegenheid in de middensegmenten. Dat is onjuist. Wat onderzoek laat zien is dat de werkgelegenheid in het middensegment minder snel groeit dan er boven of er onder. Ten tweede, is het middensegment van de loonverdeling vaak gelijk gesteld aan mbo-beroepen en is de conclusie getrokken dat de toekomst van mbo-gediplomeerden onzeker is. Ook dit klopt niet: het is waar dat groeiberoepen vaker beroepen op hbo-plus-niveau zijn en krimpberoepen (v)mbo beroepen zijn, maar mbo'ers zijn te vinden over de hele breedte van het loonspectrum van beroepen (zie ook Van den Berge en ter Weel, 2015). In het middensegment -beroepen tussen de $25^{\text {ste }}$ en $75^{\text {ste }}$ percentiel- heeft $56 \%$ een diploma op mbo-niveau. De rest is hoger of lager opgeleid. ${ }^{22}$ Beleidsmakers zouden er goed aan doen om dergelijke simplificaties te voorkomen. Daarbij komt nog dat in vergelijking met andere landen, de relatieve krimp in het middensegment in Nederland betrekkelijk klein in omvang is. Of beroepen wel of niet zullen verdwijnen, hangt in sterke mate af van de taaksamenstelling van die beroepen (Autor, 2015; Arntz et al., 2016). Over hoe de taaksamenstelling van beroepen aan het veranderen is, weten wij momenteel nog niet veel. Beleid kan overigens de processen van automatisering en internationalisering niet stoppen omdat deze zich buiten de beïnvloedingssfeer van beleidsmakers bevinden.

Wat beleid wel kan doen, is stimuleren dat studiekiezers en werkenden over de juiste set aan vaardigheden beschikken om weerbaar te zijn in veranderende marktomstandigheden. Vooral het belang van probleemoplossend vermogen en interpersoonlijke vaardigheden in het werk neemt toe, en de ontwikkeling van deze vaardigheden zouden meer aandacht moeten krijgen in het onderwijs. Het stimuleren van een leven lang leren is tevens van belang omdat de vaardigheden die nodig zijn om een beroep uit te oefenen veranderen en werkenden moeten meegaan in deze verandering. Een leven lang leren is ook van belang bij het maken van de overstap van een krimp- naar een groeiberoep. Ten slotte moet beleid er voor zorgen dat de markt goed geïnformeerd is over de veranderende

\footnotetext{
${ }^{22}$ Het is echter wel zo dat het aandeel mbo'ers in laagbetaalde beroepen (laagste kwartiel) in de afgelopen 20 jaar gestegen is en dat in de hoogbetaalde beroepen (hoogste kwartiel) gedaald, maar de ontwikkeling is zeer geleidelijk ( $0,3 \%$ per jaar).
} 
vraag naar vaardigheden zodat individuen en bedrijven meer optimale overwegingen kunnen maken in hun investeringsbeslissingen. Er gebeurt nu al e.e.a. op dit terrein, maar in mijn ogen onvoldoende. Aan de kant van het opleidingsaanbod wordt bijvoorbeeld werk gemaakt van de doelmatigheid van het onderwijs met bijvoorbeeld de Commissie Macrodoelmatigheid Hoger Onderwijs en de Commissie Macrodoelmatigheid Middelbaar Beroepsonderwijs. Echter, in het basis en voortgezet onderwijs wordt te weinig gedaan aan loopbaanbegeleiding waarbij expliciet ingegaan wordt op de arbeidsmarkt en de baankansen die jongeren wel of niet krijgen met de vervolgstudie die zij voor ogen hebben. ${ }^{23}$ Docenten hebben geen tijd om hier op in te gaan en zijn daar ook niet voor opgeleid. Dit is een terrein waar de overheid in mijn ogen in zou moeten investeren zodat jongeren in een vroeg stadium geholpen worden bij het nadenken over hun toekomst op de arbeidsmarkt en leren omgaan met arbeidsmarktinformatie (in samenspel, natuurlijk, met hun interesses en capaciteiten). ${ }^{24}$

\section{Dankwoord}

Ik ben de Rector Magnificus, hoogleraar Rianne Letschert, het College van Bestuur van Maastricht University, de decaan van de School of Business and Economics, hoogleraar Philippe Vergauwen, de voorzitter van het departement algemene economie (AE2), hoogleraar Tom van Veen en de leden van de benoemingscommissie zeer erkentelijk voor het vertrouwen dat zij in mij stellen

Mevrouw de Rector Magnificus, of ik zelf grote loopbaanplannen had toen ik aan mijn eigen studie begon, betwijfel ik. Ik zag het wel zitten om carrière te maken als fotograaf, maar mijn ouders zagen het anders. Toen ben ik maar economie gaan studeren aan de Université de Namur. Pas in mijn laatste studiejaar heeft mijn scriptiebegeleider -hoogleraar social choice Louis Gevers ${ }^{25}$ - mijn interesse weten te wekken voor wetenschappelijk onderzoek. Hij stuurde mij naar Tilburg

\footnotetext{
${ }^{23}$ Het gros van het onderzoek naar arbeidsmarktverwachtingen en -informatie richt zich op studenten (Zafar, 2011). Over hoe scholieren hun verwachtingen vormen is weinig bekend. In de Nederlandse context waarin jongeren vroege profielkeuzes moeten maken is het zeer relevant om hier aandacht voor te hebben.

24 Dit zou onderdeel kunnen zijn van de "betere loopbaanoriëntatie en -begeleiding" (Kamerbrief van wat Het Ministerie van OCW, 28 september 2016).

${ }^{25}+25-09-2004$.
} 
University om samen met hoogleraar Ruud Muffels te werken aan onderzoek naar armoede, ongelijkheid en inkomensherverdeling. Hoogleraren Ruud Muffels en Jos Berghman ${ }^{26}$ hebben mij toen de kans geven om mijn promotieonderzoek in Tilburg te doen. Zij hebben mij gestimuleerd in mijn ontwikkeling als arbeidseconoom. Wat ik ook belangrijk vind, is dat zij mij hebben aangemoedigd om als econoom aandacht te hebben voor andere vakgebieden, en mij geleerd hebben wetenschappelijk en beleidsgericht onderzoek met elkaar combineren. Ik ben hen dankbaar voor de wijze lessen.

Ik werk nu sinds november 2007 met veel genoegen bij het Researchcentrum voor Onderwijs en Arbeidsmarkt (ROA) aan deze universiteit. Dat ik met zo veel plezier elke ochtend vanuit Venray naar mijn werk kom heeft niet alleen te maken met het soort onderzoek dat ik hier doe, maar zeker ook met het feit dat ik hier te maken heb met leuke en inspirerende mensen. Graag zou ik hoogleraren en ROA directeuren Andries de Grip en Rolf van der Velden willen danken voor hun vertrouwen in mij en het feit ze mij blijven uitdagen. Ik ben er trots op dat ik met hen en hoogleraar Frank Cörvers als lid van het Management Team vorm kan geven aan het ROA onderzoek en kan bijdragen aan de nationale en internationale positionering van het instituut.

Beste ROA collega's, jullie weten dat ik erg gesteld ben op samenwerking omdat ik sterk geloof in het feit dat je ontzettend veel van elkaar kunt leren. Ik wil in het bijzonder een paar mensen danken met wie ik dagelijks intensief samenwerk: Jessie Bakens, Ineke Bijlsma, Sander Dijksman, Peter van Eldert, Annemarie KünnNelen, Raymond Montizaan en Davey Poulissen. Jullie zijn fijne collega's en ik ben blij dat ik op jullie samenwerking kan vertrouwen, of het nu gaat om projectwerkzaamheden of het werken aan wetenschappelijke papers.

Mes chers parents, je vous remercie pour tout ce que vous faites pour moi, Monique et les enfants. Chers Monique, Céleste, Blaise et Aurélie, sans votre soutien je n'en serais pas là aujourd'hui. Vous êtes une grande source de motivation pour moi.

Ik heb gezegd.

${ }^{26}+10-10-2014$. 


\section{Literatuur}

Acemoglu, D., \& Restrepo, P. (2017). Robots and Jobs: Evidence from US labor markets. NBER Working Paper No. w23285.

Almlund, M., Duckworth, A., Heckman, J., \& Kautz, T. (2011). Personality psychology and economics. In E. Hanushek, S. Machin \& L. Woessmann (red.), Handbook of the Economics of Education, vol. 4 (pp. 1-181), Amsterdam: Elsevier.

Altonji, J., Arcidiacono, P., \& Maurel, A. (2015). The analysis of field choice in college and graduate school: Determinants and wage effects. National Bureau of Economic Research, No. w21655.

Arntz, M., Gregory, T., \& Zierahn, U. (2016). The risk of automation for jobs in OECD countries: A comparative analysis. OECD Social, Employment, and Migration Working Papers, No. 189. Paris: OECD Publishing.

Arcidiacono, P., Hotz, V., \& Kang, S. (2012). Modeling college major choices using elicited measures of expectations and counterfactuals. Journal of Econometrics, 166(1), 3-16.

Autor, D. (2015). Why are there still so many jobs? The history and future of workplace automation. Journal of Economic Perspectives, 29(3), 3-30.

Autor, D., \& Dorn, D. (2013). The growth of low-skill service jobs and the polarization of the US labor market. American Economic Review, 103(5), 15531597.

Autor, D., Katz, L., \& Kearney, M (2006). The polarization of the U.S. labor market. American Economic Review, 96(2), 189-194.

Autor, D., Katz, L., \& Kearney, M. (2008). Trends in U.S. wage inequality: revising the revisionists. Review of Economics and Statistics, 90(2), 300-323.

Autor, D., Levy, F., \& Murnane, R. (2003). The skill content of recent technological change: An empirical exploration. The Quarterly journal of economics, 118(4), 1279-1333.

Bardhan, A., Hicks, D., \& Jaffee, D. (2013). How responsive is higher education? The linkages between higher education and the labour market. Applied Economics, 45(10), 1239-1256.

Beaudry, P., Green, D., \& Sand, B. (2016). The great reversal in the demand for skill and cognitive tasks. Journal of Labor Economics, 34(S1), S199-S247.

Becker, G. (1962). Investment in human capital: A theoretical analysis. Journal of Political Economy, 70(5), 9-49. 
Berge, W. Van den, \& Ter Weel, B. (2015). Baanpolarisatie in Nederland. CPB Policy Brief 2015/13.

Bijlsma, I., Dijksman, S., Fouarge, D., \& Künn-Nelen, A. (2015). Winnaars en verliezers op de arbeidsmarkt 1996-2012. Tijdschrift voor Arbeidsvraagstukken, 31(2), 106-123.

Bleemer, Z., \& Zafar, B. (2015). Intended college attendance: evidence from an experiment on college returns and costs. Federal Reserve Bank of New York Staff Report No. 739.

Bonilla, L., Bottan, N., \& Ham, A. (2016). Information policies and higher education choices: Experimental evidence from Colombia. University of Illinois, mimeo.

Bonin, H., Dohmen, T., Falk, A., Huffman, D., \& Sunde, U. (2007). Cross-sectional earnings risk and occupational sorting: the role of risk attitudes. Labour Economics, 14(6), 926-937.

Borghans, L., Duckworth, A., Heckman, J., \& Ter Weel, B. (2008a). The economics and psychology of personality traits. Journal of Human Resources, 43(4), 9721059.

Borghans, L., Golsteyn, B., \& Stenberg, A. (2015). Does expert advice improve educational choice? PloS one, 10(12), e0145378.

Borghans, L., Ter Weel, B., \& Weinberg, B. (2008b). Interpersonal styles and labor market outcomes. Journal of Human Resources, 43(4), 815-858.

Borghans, L., Ter Weel, B., \& Weinberg, B. A. (2014). People skills and the labormarket outcomes of underrepresented groups. Industrial and Labor Relations Review, 67(2), 287-334.

Buisman, M., Allen, J., Fouarge, D., Houtkoop, W., \& van der Velden, R. (2013). PIAAC: Kernvaardigheden voor werk en leven. Resultaten van de Nederlandse survey 2012. 's Hertogenbosch: ECBO.

Caroli, E., \& Van Reenen, J. (2001). Skill-biased organizational change? Evidence from a panel of British and French establishments. Quarterly Journal of Economics, 116(4), 1449-1492.

Clark, A., Diener, E., Georgellis, Y., \& Lucas, R. (2008). Lags and leads in life satisfaction: A test of the baseline hypothesis. The Economic Journal, 118(529), F222-F243.

Conlon, J. (2017). Major malfunction: A field experiment correcting undergraduates' beliefs about salaries. Federal Reserve Bank of New York, mimeo.

Deloitte (2014). De impact van automatisering op de Nederlandse arbeidsmarkt. Een gedegen verkenning op basis van Data Analytics. Deloitte. 
De Paola, M., \& Gioia, F. (2012). Risk aversion and major choice: Evidence from Italian students. Università della Calabria, Working Paper 7-2011.

Diaz-Serrano, L., \& Nilsson, W. (2017). The reliability of students' earnings expectations. Bonn: IZA DP No 10700.

Elsayed, A., De Grip, A., \& Fouarge, D. (2017). Job tasks, computer use, and the decreasing part-time pay penalty for women in the UK. British Journal of Industrial Relations, 55(1), 58-82.

Fan, W., \& Wolters, C. (2014). School motivation and high school dropout: The mediating role of educational expectation. British Journal of Educational Psychology, 84(1), 22-39.

Fleubaey, M., \& Schwandt, H. (2016). Do people seek to maximize their subjective well-being? University of Zurich, mimeo.

Fouarge, D. (2015). Project Onderwijs-Arbeidsmarkt: gebruik van arbeidsmarktinformatie en impact. Maastricht: ROA-TR-2015/4.

Fouarge, D. (2017). Vakmanschap en groei in beroepen. Vakblad Profiel, 2, 34-35.

Fouarge, D., \& de Grip, A. (2013). Complexiteit, specialisatie en effectiviteit van het werk in Nederland. In B. Ter Weel \& S. Kok (red.), De Nederlandse arbeidsmarkt in taken. Eerste bevindingen uit de Nederlandse Skills Survey (pp. 42-50). CPB: The Hague.

Fouarge, D., Kriechel, B., \& Dohmen, T. (2014). Occupational sorting of school graduates: The role of economic preferences. Journal of Economic Behavior \& Organization, 106, 335-351.

Fouarge, D., Künn-Nelen, A., \& Mommers, A. (2016). Studiekeuze en arbeidsmarkt: literatuurstudie. Maastricht: ROA-R-2016/3.

Fouarge, D., \& Levels, M. (2016). Automatisering en polarisering op de arbeidsmarkt. ESB, 4744, 27 December 2016.

Fouarge, D., Smits, W., de Vries, J., \& de Vries, R. (2017). Ongelijkheid en veranderingen in de beroepenstructuur. In K. Chkalova, J. van Genabeek, J. Sanders, W. Smits (red.), Dynamiek op de Nederlandse arbeidsmarkt. Focus op ongelijkheid (pp. 46-67). Centraal Bureau voor de Statistiek/TNO, Den Haag/Heerlen/Bonaire/Leiden.

French, R., \& Oreopoulos, P. (2017). Behavioral barriers transitioning to college. Labour Economics, forthcoming.

Frey, C., \& Osborne, M. (2017). The future of employment: how susceptible are jobs to computerisation? Technological Forecasting and Social Change, 114, 254280. 
Fricke, H., Grogger, J., \& Steinmayr, A. (2015). Does exposure to economics bring new majors to the field? Evidence from a natural Experiment. National Bureau of Economic Research, No. w21130.

Goos, M., \& Manning, A. (2007). Lousy and lovely jobs: the rising polarization of work in Britain. The Review of Economics and Statistics, 89(1), 118-133.

Goos, M., Manning, A., \& Salomons, A. (2009). Job polarization in Europe. American Economic Review, 99(2), 58-63.

Goos, M., Manning, A., \& Salomons, A. (2014). Explaining job polarization: routinebiased technological change and offshoring. American Economic Review, 104(8), 2509-2526.

Goux, D., Gurgand, M., \& Maurin, E. (2017). Adjusting your dreams? High school plans and dropout behaviour. The Economic Journal. forthcoming.

Graetz, G., \& Michaels, G. (2015). Robots at work. CEP Discussion Paper 1335.

Green, F. (2012). Employee involvement, technology and evolution in job skills: A task-based analysis. Industrial and Labor Relations Review, 65(1), 36-67.

Hanushek, E. A., Schwerdt, G., Wiederhold, S., \& Woessmann, L. (2015). Returns to skills around the world: Evidence from PIAAC. European Economic Review, 73, 103-130.

Harackiewicz, J., Rozek, C., Hulleman, C., \& Hyde, J. (2012). Helping parents to motivate adolescents in mathematics and science an experimental test of a utility-value intervention. Psychological Science, 23(8), 899-906.

Hartog, J. (2000). Over-education and earnings: where are we, where should we go? Economics of Education Review, 19(2), 131-147.

Hastings, J., Neilson, C., \& Zimmerman, S. (2015), The effects of earnings disclosure on college enrolment decisions. National Bureau of Economic Research, Working Paper 21300.

Hastings, J., Neilson, C., Ramirez, A., \& Zimmerman, S. (2016). (Un)informed college and major choice: Evidence from linked survey and administrative data. Economics of Education Review, 51, 136-151.

Heckman, J., Stixrud, J., \& Urzua, S. (2006). The effects of cognitive and noncognitive abilities on labor market outcomes and social behavior. Journal of Labor Economics, 24(3), 411-482.

Hornstra, M., de Grip, A., \& Fouarge, D. (2017). Task-domains among older versus younger workers. ROA, Universiteit Maastricht, Mimeo.

Hoxby, C., \& Turner, S. (2013). Expanding college opportunities for high-achieving, low income students. Stanford Institute for Economic Policy Research Discussion Paper, (12-014). 
Jensen, R. (2010). The (perceived) returns to education and the demand for schooling. The Quarterly Journal of Economics, 125(2), 515-548.

Jung, P., \& Kuhn, M. (2014). Labour market institutions and worker flows: comparing Germany and the US. The Economic Journal, 124(581), 1317-1342.

Katz, L. \& Autor, D. (1999). Changes in the wage structure and earnings inequality. In O. Ashenfelter \& D. Card (red.), Handbook of Labor Economics, vol. 3 (pp. 14631555), Amsterdam: Elsevier.

Kaufmann, K. (2014). Understanding the income gradient in college attendance in Mexico: The role of heterogeneity in expected returns. Quantitative Economics, 5(3), 583-630.

Kerr, S., Pekkarinen, T., Sarvimäki, M., \& Uusitalo, R. (2014). Educational choice and information on labor market prospects: A randomized field experiment. Milan, Italy: University of Milan. Working Paper.

Liu, K., Salvanes, K., \& Sørensen, E. (2016). Good skills in bad times: Cyclical skill mismatch and the long-term effects of graduating in a recession. European Economic Review, 84, 3-17.

Long, M., Goldhaber, D., \& Huntington-Klein, N. (2014). Do students' college major choices respond to changes in wages?, CALDER Working Paper 107.

Louviere, J., Hensher, D., \& Swait, J. (2000). Stated choice methods: Analysis and applications. Cambridge University Press.

McGuigan, M., McNally, S., \& Wyness, G. (2012). Student awareness of costs and benefits of educational decisions: Effects of an information campaign. CEE Discussion Paper 139.

Michaels, G., Natraj, A., \& Van Reenen, J. (2014). Has ICT polarized skill demand? Evidence from eleven countries over twenty-five years. Review of Economics and Statistics, 96(1), 60-77.

Montizaan, R., Cörvers, F., \& De Grip, A. (2010). The effects of pension rights and retirement age on training participation: Evidence from a natural experiment. Labour Economics, 17(1), 240-247.

Mortensen, D. (1994). The cyclical behavior of job and worker flows. Journal of Economic Dynamics and Control, 18(6), 1121-1142.

Munasinghe, L., \& Sicherman, N. (2006). Why do dancers smoke? Smoking, time preference, and wage dynamics. Eastern Economic Journal, 32(4), 595-616.

Murnane, R. (2013). US high school graduation rates: Patterns and explanations. Journal of Economic Literature, 51(2), 370-422.

OECD (2013). OECD skills outlook 2013: First results from the Survey of Adult Skills. Paris: OECD Publishing. 
OECD (2016). Education at a Glance 2016: OECD Indicators. Paris: OECD Publishing. Oreopoulos, P. \& Dunn, R. (2013). Information and college access: Evidence from a randomized field experiment. The Scandinavian Journal of Economics, 115(1), 326.

Pistolesi, N. (2017). Advising students on their field of study: Evidence from a French university reform. Labour Economics, 44, 106-121.

ROA (2015). De arbeidsmarkt naar opleiding en beroep tot 2020. Maastricht: ROA-R2015/6.

ROA/CBS (2015). Beroepenindeling ROA-CBS 2014 (BRC 2014). Maastricht: ROA-TR2015/5.

Ruder, A., \& Van Noy, M. (2017). Knowledge of earnings risk and major choice: Evidence from an information experiment. Economics of Education Review, 57, 80-90.

Saniter, N., \& Siedler, T. (2014). The effects of occupational knowledge: Job information centers, educational choices, and labor market outcomes. IZA Discussion Paper 8100.

Schweri, J., \& Hartog, J. (2015). Do wage expectations influence the decision to enroll in nursing college?. Bonn, IZA DP 9120.

SER (2016). Mens en technologie: Samen aan het werk. SER: Den Haag.

Somers, M., \& Fouarge, D. (2017). The role of unanticipated labour market conditions in graduates' regret of study choice. Maastricht University, mimeo.

Smits, W., \& Vries, J. de (2015). Toenemende polarisatie op de Nederlandse arbeidsmarkt. ESB, 100, 24-25.

Spitz-Oener, A. (2006). Technical change, job tasks, and rising educational demands: looking outside the wage structure. Journal of Labor Economics, 24(2), 235-270.

Vrontis, D., Thrassou, A., \& Melanthiou, Y. (2007). A contemporary higher education student-choice model for developed countries. Journal of Business Research, 60(9), 979-989.

Webbink, D., \& Hartog, J. (2004). Can students predict starting salaries? Yes! Economics of Education Review, 23(2), 103-113.

Weel, B. ter (2015). De match tussen mens en machine. Beleid en Maatschappij, 42(2), 156-170.

Weel, B. ter, \& Kok, S. (2013). De Nederlandse arbeidsmarkt in taken. Eerste bevindingen uit de Nederlandse Skills Survey. CPB: The Hague.

Weinberger, C. (2014). The increasing complementarity between cognitive and social skills. Review of Economics and Statistics, 96(4), 849-861. 
Wiswall, M. \& Zafar, B. (2015a). Determinants of college major choice: Identification using an information experiment. Review of Economic Studies, 82(2), 791-824.

Wiswall, M., \& Zafar, B. (2015b). How do college students respond to public information about earnings? Journal of Human Capital, 9(2), 117-169.

Zafar, B. (2011). How do college students form expectations?. Journal of Labor Economics, 29(2), 301-348.

Zafar, B. (2013). College major choice and the gender gap. Journal of Human Resources, 48(3), 545-595. 

Didier Fouarge (Namur, België, 1970) is sinds september 2016 hoogleraar Dynamics of skills allocation aan de Maastricht University School of Business and Economics. Hij is sinds 2007 verbonden aan het Researchcentrum voor Onderwijs en Arbeidsmarkt (ROA), waar hij verantwoordelijk is voor het onderzoeksprogramma Arbeidsmarktdynamiek. Hij is fellow bij IZA, Netspar, en GSBE. Hij houdt zich bezig met wetenschappelijk en toegepast onderzoek op het terrein van vraag en aanbod van arbeid en investeringskeuzes in menselijk kapitaal. Hij heeft gepubliceerd in onder andere Industrial Labour Relation Review, British Journal of Industrial Relations, Applied Economics, International Journal of Manpower, De Economist, International Journal of Human Resource Management, Economics of Innovation and New Technology, Journal of Social Policy, Social Indicators Research. 